\title{
Trisubstituted barbiturates and thiobarbiturates: Synthesis and biological evaluation as xanthine oxidase inhibitors, antioxidants, antibacterial and anti-proliferative agents
}

\section{Figueiredo, Joana}

2018-01-01

Figueiredo , J , Serrano , J L , Cavalheiro , E , Keurulainen , L , Yli-Kauhaluoma , J T , Moreira , V M , Ferreira , S , Domingues , F C , Silvestre , S \& Almeida , P 2018 , ' Trisubstituted barbiturates and thiobarbiturates: Synthesis and biological evaluation as xanthine oxidase inhibitors, antioxidants, antibacterial and anti-proliferative agents ' , European Journal of Medicinal Chemistry, vol. 143 , pp. 829-842 . https://doi.org/10.1016/j.ejmech.2017.11.070

http://hdl.handle.net/10138/308822

https://doi.org/10.1016/j.ejmech.2017.11.070

cc_by_nc_nd

acceptedVersion

Downloaded from Helda, University of Helsinki institutional repository.

This is an electronic reprint of the original article.

This reprint may differ from the original in pagination and typographic detail.

Please cite the original version. 


\section{Graphical Abstract}

\section{Trisubstituted barbiturates and thiobarbiturates: synthesis and biological evaluation as xanthine oxidase inhibitors, antioxidants, antibacterial and anti-proliferative agents}

Joana Figueiredo $^{\mathrm{a}, \mathrm{b}}$, João L. Serrano ${ }^{\mathrm{a}, \mathrm{b}}$, Eunice Cavalheiro ${ }^{\mathrm{a}, \mathrm{b}}$, Leena Keurulainen ${ }^{\mathrm{c}}$, Jari Yli-Kauhaluoma ${ }^{\mathrm{c}}$, Vânia M, Moreira ${ }^{\mathrm{c}, \mathrm{d}}$, Susana Ferreira ${ }^{\mathrm{a}}$, Fernanda C. Domingues ${ }^{\mathrm{a}, \mathrm{b}}$, Samuel Silvestre ${ }^{\mathrm{a}, \mathrm{e}, *}$ and Paulo

${ }^{a}$ CICS-UBI-Health Sciences Research Centre, University of Beira Interior, 6200-506 Covilhã, Portugal

${ }^{b}$ Department of Chemistry, University of Beira Interior, 6200-500 Covilhã, Portugal

${ }^{c}$ Drug Research Program, Division of Pharmaceutical Chemistry and Technology, Faculty of Pharmacy, Viikinkaari 5 E (PO Box 56), FI-00014 University of Helsinki, Helsinki, Finland

${ }^{d}$ Strathclyde Institute of Pharmacy and Biomedical Sciences, University of Strathclyde, 161 Cathedral Street, Glasgow G4 ORE, UK4

${ }^{e}$ CNC - Center for Neuroscience and Cell Biology, University of Coimbra, Rua Larga, 3004-517 Coimbra, Portugal

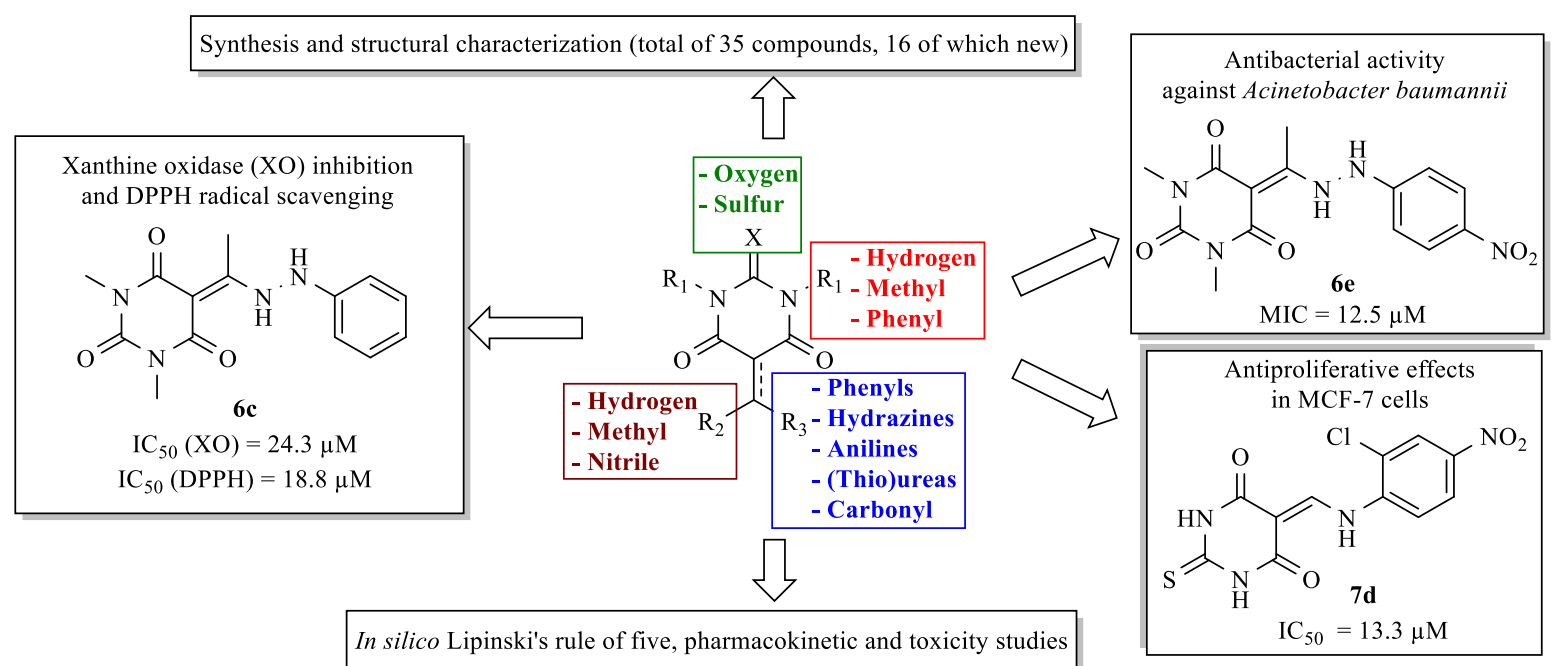




\section{Trisubstituted barbiturates and thiobarbiturates: synthesis and biological evaluation as xanthine oxidase inhibitors, antioxidants, antibacterial and anti-proliferative agents}

Joana Figueiredo ${ }^{\mathrm{a}, \mathrm{b}}$, João L. Serrano ${ }^{\mathrm{a}, \mathrm{b}}$, Eunice Cavalheiro ${ }^{\mathrm{a}, \mathrm{b}}$, Leena Keurulainen ${ }^{\mathrm{c}}$, Jari Yli-Kauhaluoma ${ }^{\mathrm{c}}$, Vânia M. Moreira $^{\mathrm{c}, \mathrm{d}}$, Susana Ferreira ${ }^{\mathrm{a}}$, Fernanda C. Domingues ${ }^{\mathrm{a}, \mathrm{b}}$, Samuel Silvestre ${ }^{\mathrm{a}, \mathrm{e}, *}$ and Paulo Almeida ${ }^{\mathrm{a}, \mathrm{b}}$

${ }^{a}$ CICS-UBI-Health Sciences Research Centre, University of Beira Interior, 6200-506 Covilhã, Portugal

${ }^{b}$ Department of Chemistry, University of Beira Interior, 6200-500 Covilhã, Portugal

${ }^{c}$ Drug Research Program, Division of Pharmaceutical Chemistry and Technology, Faculty of Pharmacy, Viikinkaari 5 E (PO Box 56), FI-00014 University of Helsinki, Helsinki, Finland

${ }^{d}$ Strathclyde Institute of Pharmacy and Biomedical Sciences, University of Strathclyde, 161 Cathedral Street, Glasgow G4 ORE, UK4

${ }^{e}$ CNC - Center for Neuroscience and Cell Biology, University of Coimbra, Rua Larga, 3004-517 Coimbra, Portugal

*Tel.: +351275329002; Fax: +351275329099; E-mail: samuel@fcsaude.ubi.pt

\section{ABSTRACT}

Barbituric and thiobarbituric acid derivatives have become progressively attractive to medicinal chemists due to their wide range of biological activities. Herein, different series of 1,3,5-trisubstituted barbiturates and thiobarbiturates were prepared in moderate to excellent yields and their activity as xanthine oxidase inhibitors, antioxidants, antibacterial agents and as anti-proliferative compounds was evaluated in vitro. Interesting bioactive barbiturates were found namely, 1,3-dimethyl-5-[1-(2-phenylhydrazinyl)ethylidene]pyrimidine-2,4,6(1H,3H,5H)-trione (6c) and 1,3-dimethyl-5-[1-[2-(4-nitrophenyl)hydrazinyl]ethylidene]pyrimidine-2,4,6(1H,3H,5H)-trione $(\mathbf{6 e})$, which showed concomitant xanthine oxidase inhibitory effect ( $\mathrm{IC}_{50}$ values of 24.3 and $27.9 \mu \mathrm{M}$, respectively), and 2,2-diphenyl-1picrylhydrazyl (DPPH) radical scavenging activity ( $\mathrm{IC}_{50}$ values of 18.8 and $23.8 \mu \mathrm{M}$, respectively). In addition, 5-[1(2-phenylhydrazinyl)ethylidene]pyrimidine-2,4,6(1H,3H,5H)-trione (6d) also revealed DPPH radical scavenger effect, with an $\mathrm{IC}_{50}$ value of $20.4 \mu \mathrm{M}$. Moreover, relevant cytotoxicity against MCF-7 cells $\left(\mathrm{IC}_{50}=13.3 \mu \mathrm{M}\right)$ was observed with 5-[[(2-chloro-4-nitrophenyl)amino]methylene]-2-thioxodihydropyrimidine-4,6(1H,5H)-dione (7d). Finally, different 5-hydrazinylethylidenepyrimidines revealed antibacterial activity against Acinetobacter baumannii (MIC values between 12.5 to $25.0 \mu \mathrm{M}$ ) which paves the way for developing new treatments for infections caused by this Gram-negative coccobacillus bacterium, known to be an opportunistic pathogen in humans with high relevance 
in multidrug-resistant nosocomial infections. The most promising bioactive barbiturates were studied in silico with emphasis on compliance with the Lipinski's rule of five as well as several pharmacokinetics and toxicity parameters.

Keywords: barbiturates; xanthine oxidase inhibition; antioxidant; antibacterial; cytotoxicity. 


\section{Introduction}

Barbituric acid (BA) is a relevant pyrimidine derivative that was synthesized for the first time in 1864 by cyclization of urea and malonic acid [1]. Until the commercialization of benzodiazepines in the 1960s, barbiturates were almost the only group of drugs used as sedative-hypnotics $[2,3]$. More recently, this class of compounds has become increasingly attractive to medicinal chemists due to the discovery that they bear a wide range of biological activities. More specifically, several of these compounds are enzyme inhibitors [collagenase-3, matrix metalloproteinases (MMPs) [4], xanthine oxidase (XO) [5] and methionine aminopeptidase-1] as well as antibacterial, anticancer, antiangiogenic, immunomodulatory, antifungal and antioxidant agents [6-9]. These activities are associated to several structural changes at positions $N 1, N 3, C 2$ and $C 5$, the latter being the most studied position. Within these structural modifications, various cyclization reactions at $C 5$ and $C 6$ of $\mathrm{BA}$, thiobarbituric acid (TBA) and their derivatives (BADs and TBADs, respectively) [10-19] as well as at $C 5$ with spiro formation [20-24] have been described. Interestingly, some of these transformations involve a multicomponent reaction (MCR) $[11,14,16]$. However, in most cases, the cyclization path is preceded by the formation of substituted methyl $[10,18]$, arylidene $[12,15,19-24]$, or methylene $[13,17,19]$ derivatives at $C 5$ as key isolated or potential precursors of these modified pyrimidines.

Among the most important $C 5$ functionalized BAs and TBAs are the 5-benzylidene or 5-methylene derivatives, usually produced usually by their reaction with benzaldehydes or triethyl orthoformate, respectively. Out of these, a large variety of 5-arylidene BADs and TBADs have been biologically evaluated and several compounds of this class was found to possess XO inhibitory effect [5] and antimicrobial activity against a number of Gram-positive and Gram-negative bacteria, as well as against fungal strains [25]. Methylene BADs and TBADs are most often used as intermediates for the synthesis of other derivatives [26, 27]. Within these, hydrazone BADs have the ability to inhibit fungal growth in the $\mu \mathrm{M}$ range [28]. In addition, through the introduction of urea, thiourea, guanidine, hydrazine or hydroxylamino groups to BADs and TBADs, new bioactive compounds can be obtained [13, 17, 29].

$\mathrm{XO}$ is an important and versatile molybdo-flavoprotein responsible for the oxidation of purine substrates, catalyzing the conversion of hypoxanthine into xanthine and xanthine into uric acid, with subsequent reduction of oxygen, forming reactive oxygen species (ROS) which include the superoxide anion radical. An 
increase in this enzyme's activity, as well as in its metabolites levels (uric acid and ROS), are associated with many pathological conditions, including gout and oxidative damage of tissues [30-32]. Therefore, the discovery of new XO inhibitors, preferably with antioxidant capacity, is an important goal in medicinal chemistry [33].

Infections caused by microorganisms, especially those involving multidrug-resistant strains, place public health at serious risk. Acinetobacter baumannii is a bacterial species increasingly associated with nosocomial infections. Risk factors for an infection with this bacterium include prolonged hospitalization and recent surgical procedures. In this context, the identification of new antibacterial agents against $A$. baumannii, with new mechanisms of action, is an object of major efforts by the scientific community [34].

Taken together, the basic BA and TBA scaffolds may play a critical role in both XO inhibitory and promoting antibacterial effects. Therefore, in search for new active BADs and TBADs with these activities, herein we describe the synthesis and in vitro biological evaluation of 35 (16 new) 1,3,5-trisubstituted barbiturates and thiobarbiturates where position 5 was conveniently substituted with methylene, benzylidene and methyl derivatives. All BADs and TBADs were evaluated as XO inhibitors and their antioxidant activity was determined using the 1,1-diphenyl-2-picrylhydrazyl (DPPH) radical scavenging method. In addition, their antibacterial activity against several Gram-positive and Gram-negative strains and cytotoxicity towards normal human dermal fibroblasts (NHDF) and a mammalian cancer cell line (MCF-7) were assessed. Structure-activity relationships were also discussed and relevant pharmacokinetic and toxicity properties were calculated in silico to evaluate their potential interest for in vivo applications and/or in the development of compounds with improved pharmacological properties.

\section{Results and discussion}

\subsection{Chemistry}

Thirty-five BADs and TBADs were synthesized as shown in Scheme 1, in moderate to excellent yields, i.e. 41-97\% (Experimental section and Table S1). The majority of 5-substituted BAD and TBAD families described herein are known precursors of fused heterocycles reported in the literature $[10,12,13,15,17-24]$. 
From this set of compounds and to the best of our knowledge, two 5-phenylcyanomethylpyrimidines (4a-b), one 5-hydrazinylethylidenepyrimidine (6a), seven 5-phenylaminomethylenepyrimidines (7a-g) and six 1(pyrimidine-5-ylidene)ureas and thioureas (8a-c, e-g) are described for the first time. All starting materials were commercially obtained, except 1,3-diphenylthiobarbituric acid (1a) which was synthesized from phenylisothiocyanate, aniline, malonic acid and acetyl chloride, in two steps [35, 36]. Almost all prepared 5substituted BADs and TBADs were easily isolated in a high degree of purity by simple filtration, as confirmed by nuclear magnetic resonance (NMR) spectra. In general, the BADs yields were higher than their congener TBADs. 


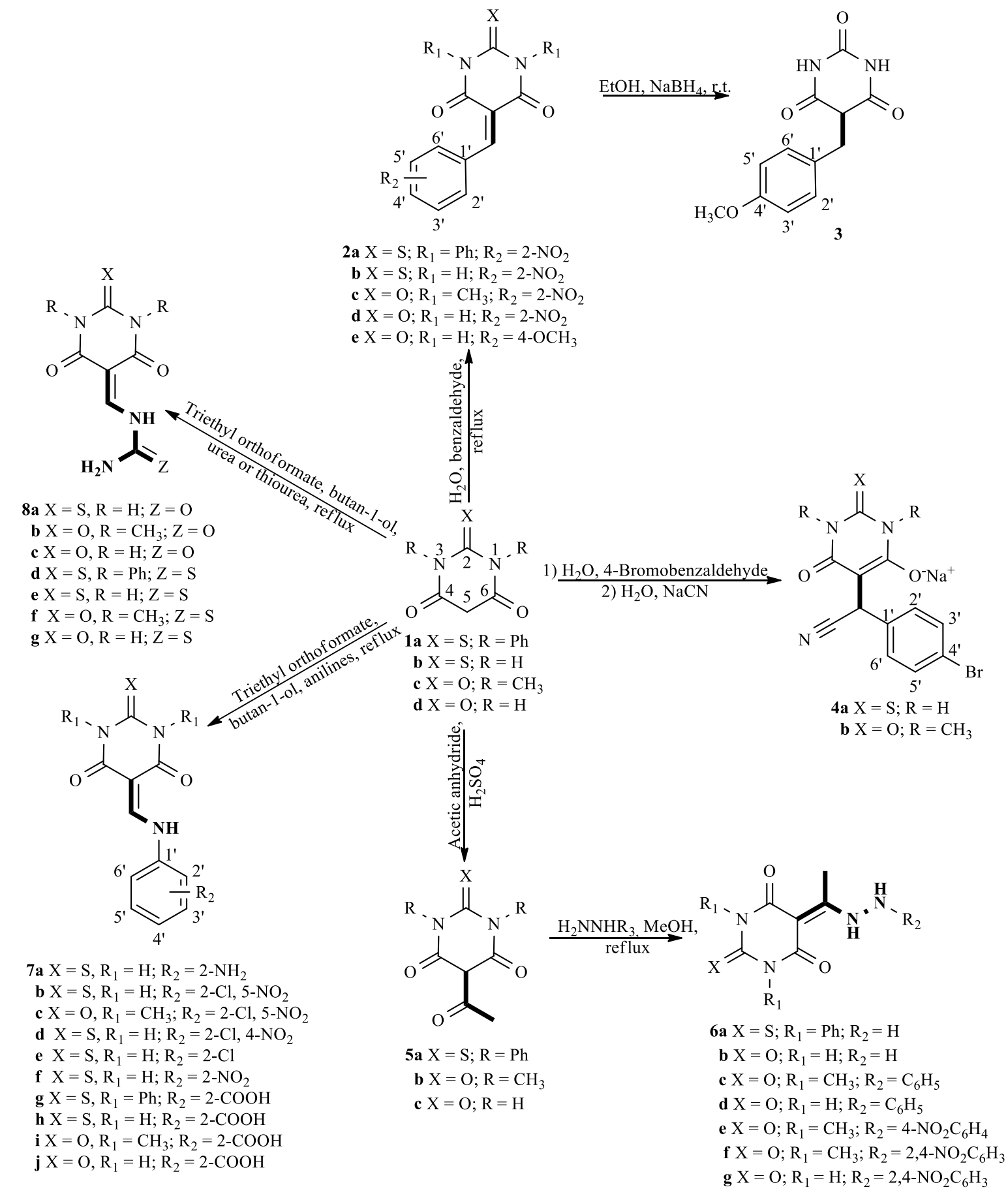

Scheme 1. Chemical synthesis of BADs and TBADs 2-8. 
A full spectroscopic characterization of all 5-substituted BADs and TBADs $\mathbf{2 - 8}$ was made, including ${ }^{1} \mathrm{H}$ and ${ }^{13} \mathrm{C}$-NMR shift assignments, which were established whenever possible with the aid of distortionless enhancement by polarization transfer (DEPT), heteronuclear multiple quantum coherence (HMQC) and heteronuclear multiple bond correlation (HMBC) experiments. The most representative ${ }^{1} \mathrm{H}-$ and ${ }^{13} \mathrm{C}-\mathrm{NMR}$ chemical shifts of 5-substituted BADs and TBADs 2-8 are presented in Tables S2 and S3, corresponding to the structural moiety depicted in bold, in Scheme 1.

5-Benzylidenepyrimidines 2a-e were synthesised by a Knoevenagel condensation reaction in excellent yields (90-97\%), based on the method reported by Deb et al. [37] in which the reaction temperature was changed from $70{ }^{\circ} \mathrm{C}$ to reflux. Then, the $\mathrm{C}-5$ double bond of 5-benzylidenepyrimidine $2 \mathbf{e}$ was reduced at room temperature by $\mathrm{NaBH}_{4}$ in ethanol according to the method described by Yan et al. [38] to give compound 3, in $41 \%$ yield. The change of the yellow arylidene color to white, due to a conjugation extension reduction, together with the absence of the ${ }^{1} \mathrm{H}-\mathrm{NMR}$ singlet at $8.25 \mathrm{ppm}(\mathbf{2 e}$ unsaturated methine $\mathrm{CH}$ ) and the observation of a triplet and doublet signals corresponding to the methine and methylene in adjacent carbons at 3.82 and 3.19 ppm, respectively, observed in the ${ }^{1} \mathrm{H}-\mathrm{NMR}$ spectra of $\mathbf{3}$, are the most important evidences of a successful reduction reaction. Additionally, the cyanomethyl derivatives 4a-b were obtained, in 67-77\% yield, from the respective 5-(4-bromobenzylidene)pyrimidines followed by the addition of sodium cyanide [39]. Once again the reduction was evidenced by the change in color of the solid to white and by observation of deshielded methylene $\mathrm{CH}{ }^{1} \mathrm{H}-\mathrm{NMR}$ singlet signals at 5.24-5.35 ppm for compounds 4a-b.

The 5-acetylpyrimidines 5a-c were synthetized using the process described by Jursic et al. [40] in good to very good yields (45-83\%). Then, their hydrazine derivatives 6a-g were easily prepared after reaction with hydrazine and different phenylhydrazines, in refluxing methanol, using the method described by the same authors [40], also in good to very good yields (50-92\%).

The 5-phenylaminomethylenepyrimidines $\mathbf{7 a - j}$ and 1-(pyrimidin-5-ylidene)ureas/thioureas $\mathbf{8 a - g}$ were obtained in moderate to very good yields $(52-98 \%)$ by reaction of triethyl orthoformate with urea or thiourea and different anilines, respectively, in refluxing butan-1-ol, by a MCR based on the method described by Rauf et al. [27]. In this procedure, the solvent was exchanged from butan-2-ol to butan-1-ol, which allowed the 
increase of the reflux temperature, resulting in higher yields of products. As representative examples, the yields of 5-phenylaminomethylenepyrimidines $\mathbf{7 h}$ and $\mathbf{7 j}$ were changed from 82 and $72 \%$ to 97 and $84 \%$, respectively, when the reaction temperature increased.

Detailed ${ }^{1} \mathrm{H}$ - and ${ }^{13} \mathrm{C}-\mathrm{NMR}$ analysis suggested that the enamine tautomer form $\mathbf{A}$ was present in all pyrimidine derivatives 6-8, in DMSO- $d_{6}$. The imine form (hydrazone) $\mathbf{B}$ appears to be absent (Figure 1), contrary to what was reported for 5-hydrazinylethylidenepyrimidines [28]. Specifically, the $\mathrm{NH}{ }^{1} \mathrm{H}-\mathrm{NMR}$ signal between 11.10 and $13.57 \mathrm{ppm}$ correlated to the 5-C signal in HMBC experiments, which makes unequivocal evidence of the exclusive existence of tautomer A in DMSO- $d_{6}$.

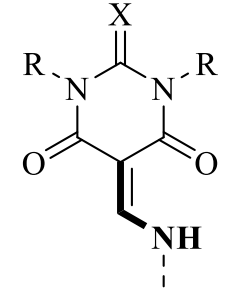

A<smiles>[X]C1=C([R])N([R])C(=O)C(/C=N/I)C1=O</smiles>

B

$$
\mathrm{X}=\mathrm{O}, \mathrm{S} ; \mathrm{R}=\mathrm{H}, \mathrm{CH}_{3}, \mathrm{Ph}
$$

Figure 1. Enamine A and imine $\mathbf{B}$ tautomeric forms.

\subsection{Xanthine oxidase inhibitory activity}

The evaluation of the XO inhibitory activity of BADs and TBADs $\mathbf{2 - 8}$ was made using a spectrophotometric method, under aerobic conditions, with xanthine as the substrate, and following uric acid formation by measuring the absorbance at $295 \mathrm{~nm}$, as described in the literature [41, 42]. The commercial drug allopurinol was used as the positive control. The study started with a screening at $30 \mu \mathrm{M}$ concentration (Table S4) and after this preliminary evaluation, concentration-response studies were performed for the BADs and TBADs which presented an inhibitory effect of $40 \%$ or higher, in order to determine their half maximal inhibitory concentration $\left(\mathrm{IC}_{50}\right)$ values.

In general, the majority of BADs and TBADs was able to inhibit XO activity (Table S4), with the most active compounds being the 5-benzylidenepyrimidines $\mathbf{2 c}$ and $\mathbf{2 d}$ and the 5-hydrazinylethylidenepyrimidines 
6c and 6e (Figure 2), with an $\mathrm{IC}_{50}$ of 26.1, 31.5, 24.3 and $27.9 \mu \mathrm{M}$, respectively (Table 1). For the positive control (allopurinol) and under the assay conditions employed, an $\mathrm{IC}_{50}$ value of $3.17 \mu \mathrm{M}$ was calculated, which is in agreement with the reported values [43]. Through the analysis of all these results, some important structural features for the XO inhibition could be inferred. Generally, BADs showed better XO inhibitory effect in comparison to their congeners TBADs, and bulkier substituents at C5 and smaller groups at N1 and N3 (Scheme 1) also seemed to favour this activity. Moreover, the 5-hydrazinylethylidenepyrimidine 6c, substituted with a methyl group at N1 and N3, clearly presented better activity than its hydrogenated analogue 6d. Additionally, the presence of a 2,4-dinitro system (6f) seemed to reduce this activity when compared to the congeners 5-hydrazinylphenyl $\mathbf{6 c}$ and 4-nitrophenyl 6e (Figure 2).

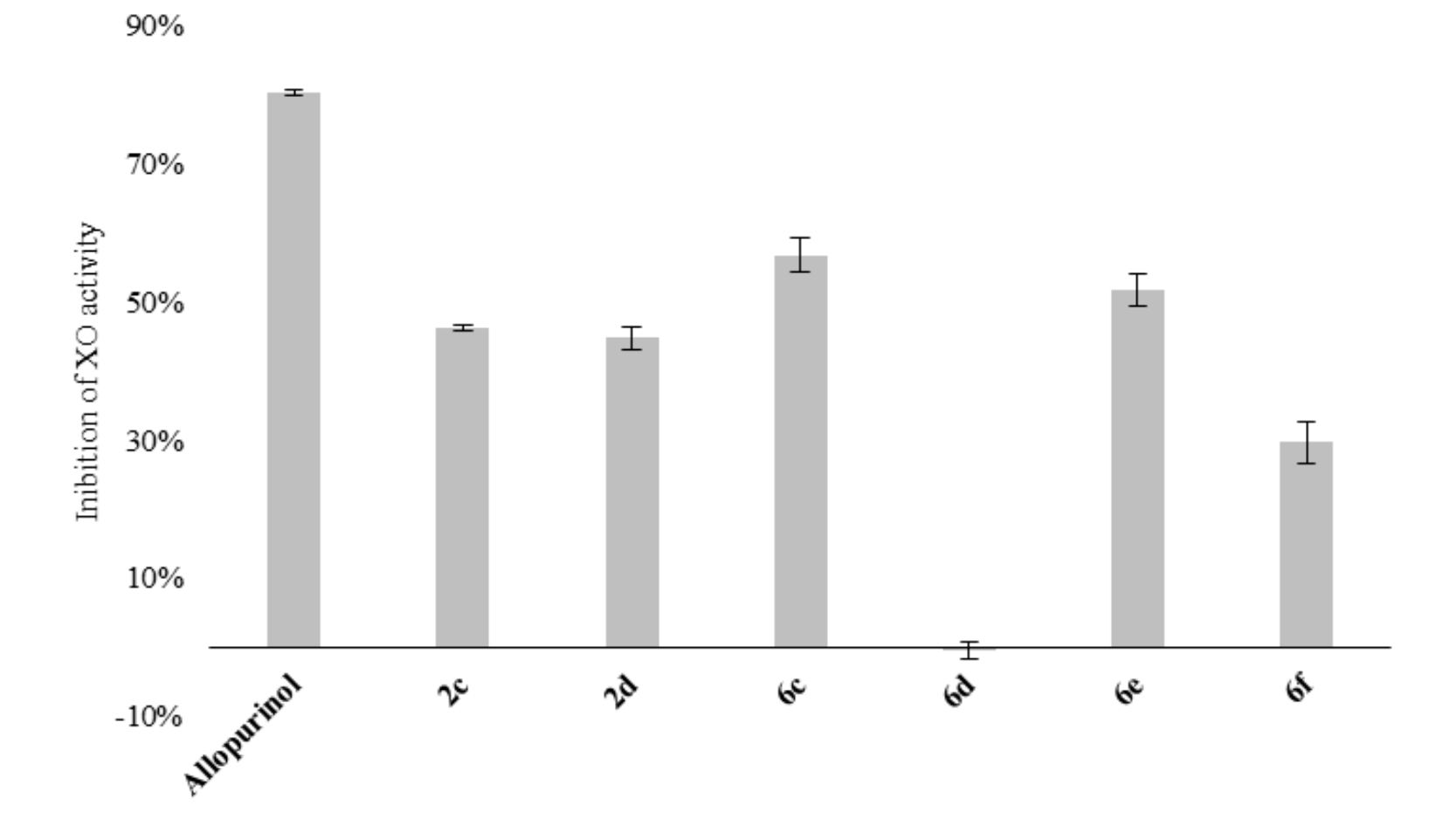

Figure 2. In vitro XO inhibitory activity of compounds $\mathbf{2 c}, \mathbf{2 d}, \mathbf{6 c - f}$ and allopurinol. Results are expressed as average values \pm standard error of the mean (SEM). A $p<0.05$ versus negative control in the statistical significance analysis (Student's $t$-test) was observed for all compounds except for $\mathbf{6 d}$.

Table 1. In vitro $\mathrm{IC}_{50}$ values for $\mathrm{XO}$ inhibition and $\mathrm{DPPH}$ radical scavenging activity of compounds $\mathbf{2 c}$, 2d, 6c-e and respective references allopurinol and Trolox. 


\begin{tabular}{cccc}
\hline & \multirow{2}{*}{ Compound } & $\mathrm{XO}(\mu \mathrm{M})^{\mathrm{a}}$ & \multicolumn{2}{c}{$\mathrm{DPPH}(\mu \mathrm{M})^{\mathrm{a}}$} \\
\cline { 3 - 4 } $\mathbf{2 c}$ & 26.1 & $\mathrm{nd}^{\mathrm{b}}$ & $\mathrm{nd}^{\mathrm{b}}$ \\
$\mathbf{2 d}$ & 31.5 & $\mathrm{nd}^{\mathrm{b}}$ & $\mathrm{nd}^{\mathrm{b}}$ \\
$\mathbf{6 c}$ & 24.3 & 22.6 & 18.8 \\
$\mathbf{6 d}$ & $\mathrm{nd}^{\mathrm{b}}$ & 23.9 & 20.4 \\
$\mathbf{6 e}$ & 27.9 & 23.9 & 23.8 \\
Allopurinol & 3.2 & $\mathrm{nd}^{\mathrm{b}}$ & $\mathrm{nd}^{\mathrm{b}}$ \\
Trolox & $\mathrm{nd}^{\mathrm{b}}$ & 33.8 & 35.9 \\
\hline
\end{tabular}

${ }^{\mathrm{a}} \mathrm{IC}_{50}$ values represent as mean of three determinations.

${ }^{\mathrm{b}}$ nd: not determined

\subsection{Antioxidant activity as DPPH radical scavenger}

The DPPH radical scavenging activity of BADs and TBADs $\mathbf{2 - 8}$ was evaluated using a spectrophotometric method by measuring the absorbance of this radical at $517 \mathrm{~nm}$, based on the available literature [41, 42] and using Trolox as the reference compound. A screening was first performed at the concentration of $30 \mu \mathrm{M}$, after 20 and 60 minutes of incubation (Table S4). $\mathrm{IC}_{50}$ values were further determined for BADs and TBADs which presented a DPPH radical scavenging activity higher than 50\% (Table 1).

Most of the tested compounds presented no appreciable DPPH radical scavenging capacity (Table S4). However, 5-hydrazinylethylidenepyrimidines 6c-e were clear exceptions (Figure 3) and the determined $\mathrm{IC}_{50}$ values were $22.6,23.9$ and $23.9 \mu \mathrm{M}$, respectively, at 20 minutes, and 18.8, 20.4 and $23.8 \mu \mathrm{M}$, at 60 minutes (Table 1). Particularly, under these experimental conditions, the radical scavenging ability of these 5hydrazinylethylidenepyrimidines was superior to the one observed with Trolox, whose calculated $\mathrm{IC}_{50}$ values (33.8 and $35.9 \mu \mathrm{M}$ after 20 and 60 minutes, respectively) are in agreement with the literature [44]. Concerning the structural features relevant for this activity, the hydrazinyl derivatives globally presented higher DPPH radical scavenging capacity when compared with most of the other compounds. More specifically, the aromatic 5-hydrazinylethylidenepyrimidines 6c-e can be relevant starting points to develop improved antioxidant compounds acting as radical scavengers. In addition, it is interesting to note that the 5hydrazinylphenyl 6c-d and 5-hydrazinyl-(4-nitrophenyl) 6e derivatives had better activity than their hydrogenated 6a-b or 2,4-dinitrophenyl 6f-g counterparts. In this context, it is worth mentioning that the 
antioxidant action of other different organic hydrazines has already been described [45-47]. Finally, the 1(pyrimidin-5-ylidene)ureas $\mathbf{8 d}$ and $\mathbf{8 f}$ exhibited a moderate radical scavenging activity (Figure 3).

$90 \%$

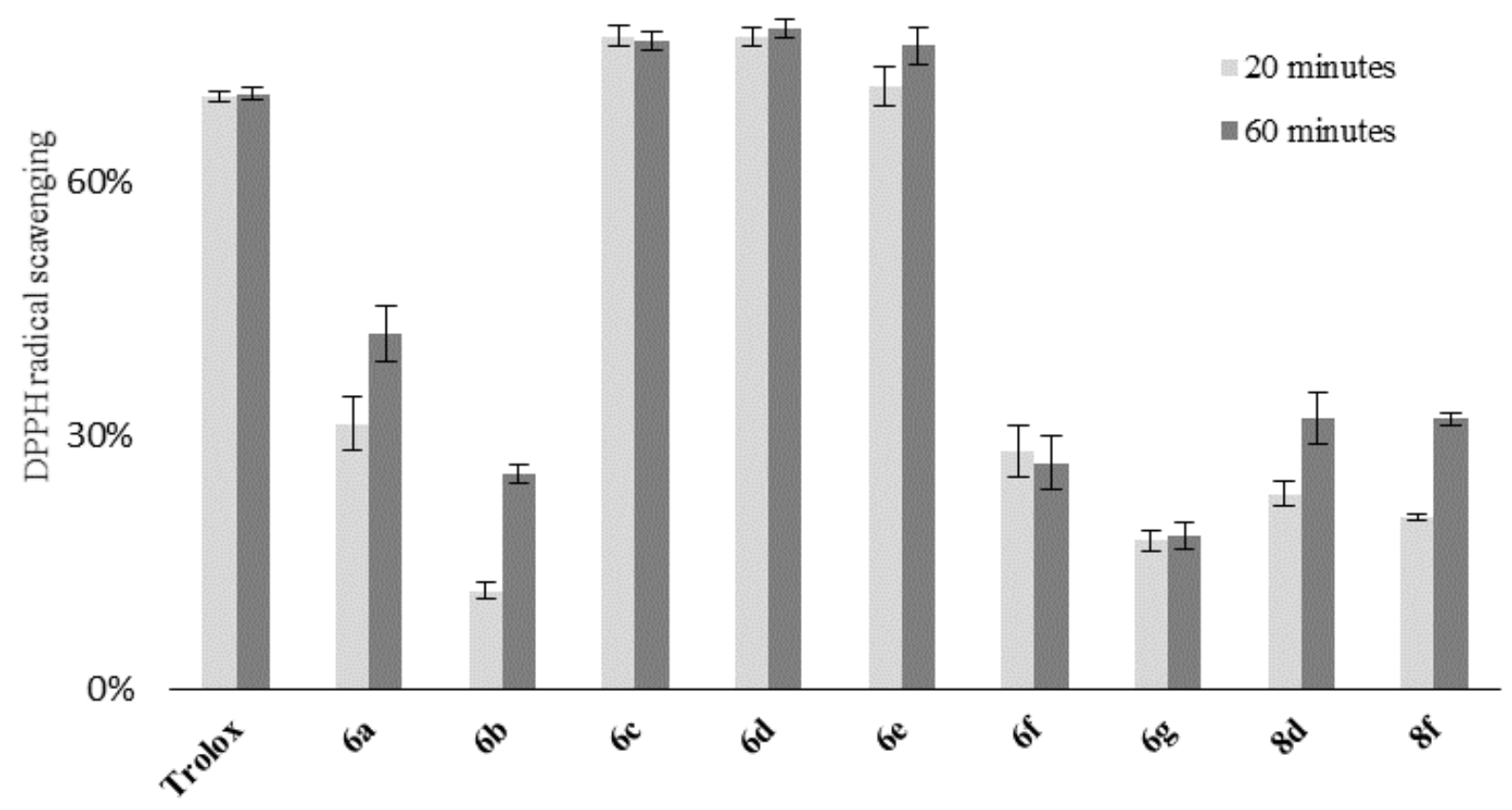

Figure 3. In vitro DPPH radical scavenging activity for 5-hydrazinylethylidenepyrimidines 6a-g, 1(pyrimidin-5-ylidene)ureas 8d, $8 \mathbf{f}$ and Trolox (positive control). Results are expressed as average values \pm SEM. A $p<0.05$ versus negative control in the statistical significance analysis (Student's $t$-test) was observed for all compounds.

Taken together, it is important to note the relevant XO inhibition and the high DPPH radical scavenging activity of the 5-hydrazinylethylidenepyrimidines $\mathbf{6 c}$ and $\mathbf{6 e}$. As the new XO inhibitors should have a remarkable radical scavenging capacity, these results seem promising [43]. 
The antibacterial potential of all synthesized BADs and TBADs 2-8 was studied in Bacillus cereus, Staphylococcus aureus, Escherichia coli, Klebsiella pneumoniae, Pseudomonas aeruginosa, Salmonella enterica subsp. enterica serovar Typhimurium and Acinetobacter baumannii strains, using tetracycline as the reference compound (Table S5).

Regarding the antibacterial activity of the compounds under study, most of the assayed BADs and TBADs did not show activity against the tested Gram-positive and Gram-negative bacterial strains, with minimum inhibitory concentrations (MIC) higher than $200 \mu \mathrm{M}$. These results are in agreement with the previous reports referring to several 5-functionalized BADs and TBADs which were inactive against different strains of bacteria and fungi [28, 48-50]. However, pyrimidines 6c-d (MIC $25.0 \mu \mathrm{M}$ ) and 6e (MIC $12.5 \mu \mathrm{M}$ ) exhibited a relevant and selective antibacterial activity against $A$. baumannii. In fact, the presence of a $p$-nitrophenyl moiety bound to the hydrazine group of 5-hydrazinylethylidenepyrimidines (Scheme 1) seems to play an important role, since an increase in this antibacterial activity was observed in relation to the unsubstituted phenyl analogs 6c-d. In addition, the presence of more than one nitro group in the phenyl group (2,4dinitrophenyl derivatives $\mathbf{6 f - g}$ ) decreased the activity of these 5-hydrazinylethylidenepyrimidines. Hence, a suitable aromatic substituent at $\mathrm{R}_{3}$ of these pyrimidines can favour this activity. Furthermore, it is important to note that compound 6d, with unsubstituted pyrimidinone nitrogens, had antibacterial activity against $A$. baumannii but was devoid of XO inhibitory effects.

The emergence of infections and outbreaks associated with strains of A. baumannii resistant to antibiotics, or even extensively drug-resistant and pandrug-resistant, has highlighted the lack of available drugs to treat infections by this bacterium. In fact, carbapenem-resistant $A$. baumannii is marked as one of the critical pathogens in the World Health Organization priority list for research and development of new antibiotics [51]. Therefore, the activity of compounds 6c-e against A. baumannii makes them promising new starting points for the development of antibacterial agents against this high-profile pathogen.

\subsection{Cytotoxicity studies in human cells}


Considering the relevant results observed in the XO inhibition, DPPH radical scavenging and antibacterial studies, the cytotoxicity of BADs and TBADs $\mathbf{2 - 8}$ was evaluated in normal human dermal fibroblasts (NHDF). Additionally, a mammalian breast cancer cell line (MCF-7) was included in this study to evaluate the anti-proliferative potential and selectivity of these compounds. The well-established 3-(4,5dimethylthiazolyl-2)-2,5-diphenyltetrazolium bromide (MTT) cell proliferation assay [52] was used in which the soluble yellow MTT is converted into purple and insoluble formazan crystals by active mitochondrial lactate dehydrogenases of living cells [53]. Initially, both cell lines were exposed to BADs and TBADs $\mathbf{2 - 8}$ at the concentration of $30 \mu \mathrm{M}$, during a period of $72 \mathrm{~h}$. Untreated cells were used as the negative control and cells treated with 5-fluorouracil (5-FU) as the positive control.

The results (Table S4) showed that most of the compounds were not markedly cytotoxic for NHDF cells at $30 \mu \mathrm{M}$. Additionally, the $\mathrm{IC}_{50}$ of 5-hydrazinylethylidenepyrimidine $\mathbf{6 c}$ was determined as a representative example of pyrimidines $\mathbf{6 c - e}$, and a value of $82.0 \mu \mathrm{M}$ was obtained. Considering the potential future use of this type of compounds in the treatment of A. baumannii infections, this can be an interesting result as it demonstrates a possible selectivity of these agents for bacterial versus normal human cells.

On the other hand, a more marked reduction of MCF-7 cells proliferation was observed (Figure 4 and Table S4). The phenylaminomethylpyrimidines 7 seemed to have higher cytotoxicity than the other groups of compounds. Specifically, it is clear that the 5-hydrazinylethylidenepyrimidine $6 \mathbf{d}$ and the 5phenylaminomethylenepyrimidines $\mathbf{7 d - e , g - h}$ have a relevant anti-proliferative effect at $30 \mu \mathrm{M}$. In this last group, the presence of a chloro or a carboxyl group at position 2 of the aromatic ring (Scheme 1) seems to improve this activity when compared to the compound containing the nitro (7f) group in the same position. For the 5-phenylaminomethylenepyrimidine 7d, the most cytotoxic compound in MCF-7 cells at $30 \mu \mathrm{M}$, the $\mathrm{IC}_{50}$ value was $13.3 \mu \mathrm{M}$. Considering its selectivity for cancer cells versus NHDFs, this structure can be a future starting point to develop this class of compounds as potential novel anticancer agents. 


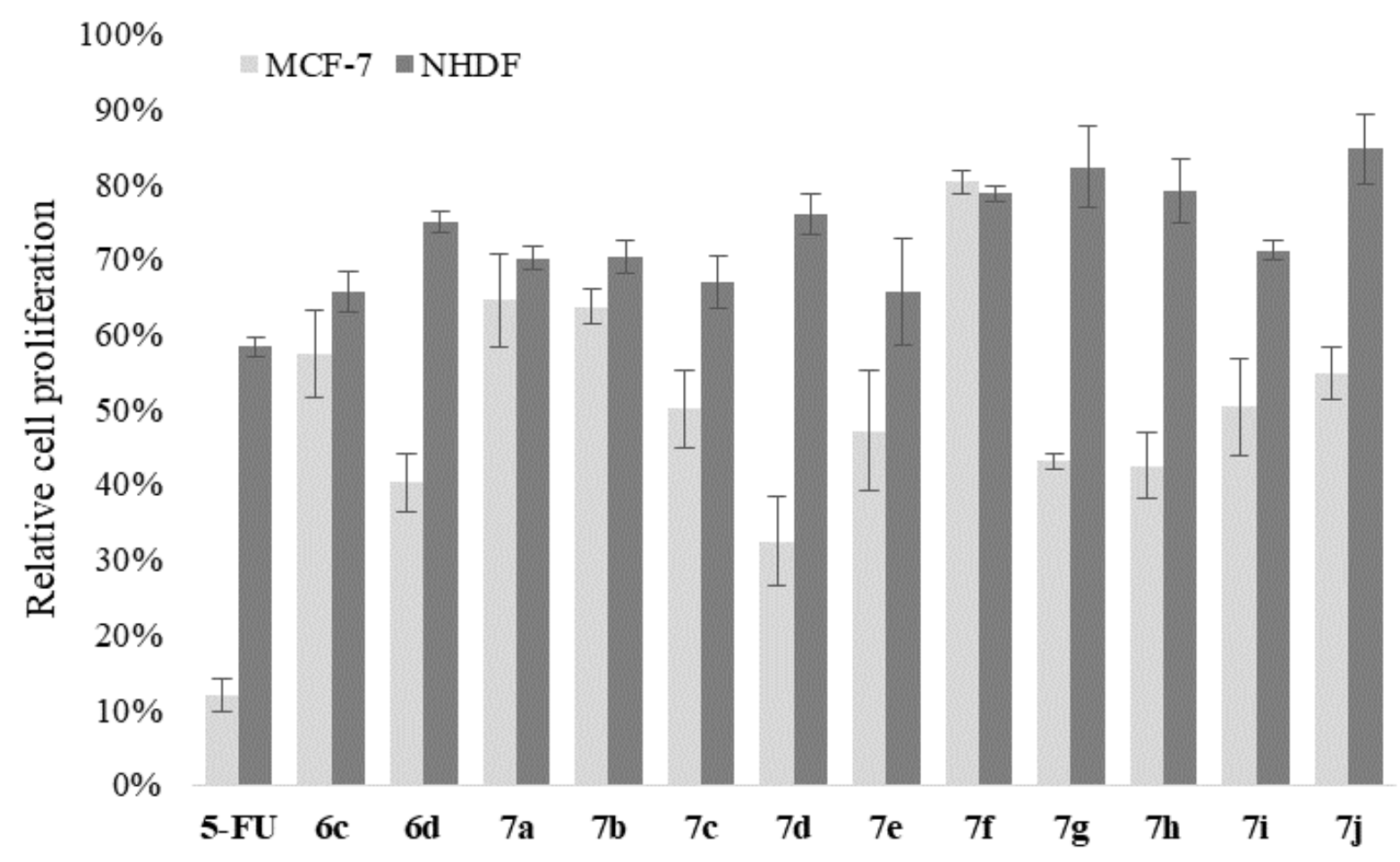

Figure 4. In vitro cytotoxic effect of compounds $\mathbf{6 c}, \mathbf{6 d}, 7 \mathbf{a}-\mathbf{j}$ and 5-fluorouracil (5-FU) in normal human dermal fibroblasts (NHDF) and in mammalian breast cancer cells (MCF-7). Results are expressed as average values \pm SEM. A $p<0.05$ versus negative control in the statistical significance analysis (Student's $t$-test) was observed for all compounds.

\subsection{In Silico studies}

Poor pharmacokinetics and/or unacceptable side effects are the main reasons why the majority of drugs evaluated in clinical trials do not reach the market [54]. Thus, computational approaches to predict the absorption, distribution, metabolism, excretion and toxicity (ADMET) may be a decisive tool to minimize these risks. The PkCSM online software (available from http://bleoberis.bioc.cam.ac.uk/pkcsm/prediction) is a recent freely accessible web platform that allows rapid evaluation of pharmacokinetic and toxicity properties and was herein used for the in silico evaluation of the drug-likeness, in terms of the Lipinski's rule of five (Table S6), and to predict ADMET properties (Table S7) for the six most promising pyrimidines (2c,d, 6c-e and 7d) tested in vitro. 
Four parameters are taken into consideration in the Lipinski's rule of five, including an $n$-octanol-water partition coefficient $(\log P$ ) no higher than 5, a molecular weight (MW) lower than $500 \mathrm{Da}$, no more than 10 hydrogen bond acceptors (n-HBA) and no more than 5 hydrogen bond donors (n-HBD) [54]. Generally, an orally active drug has no more than one violation [55]. According to Table S6, all these pyrimidines are compatible with the parameters of the Lipinski's rule of five, suggesting that these compounds have favourable properties to accomplish the drug-likeness criteria.

The pkCSM online software was also used to predict pharmacokinetic and toxicity properties of pyrimidines 2c-d, $\mathbf{6 c - e}$ and 7d (Table S7). The pyrimidines $\mathbf{2 c , d}, \mathbf{6 c - e}$ and $\mathbf{7 d}$ entirely fulfil the Lipinski's rule of five and a good intestinal absorption was predicted. However, for compounds $2 \mathbf{d}$ and $\mathbf{6 d - e}$ a poor Caco-2 permeability was estimated. In addition, despite the fact that pyrimidines $6 \mathbf{e}$ and $7 \mathbf{d}$ can be potential Pglycoprotein substrates, it was predicted that all studied compounds should not be potential P-glycoprotein I/II inhibitors. Therefore, a low probability of pharmacokinetic interactions involving this protein is expected. A similar situation should occur in the case of the excretory protein organic cation transporter 2 (OCT2). In the distribution field, a generic tendency for a low probability for these compounds to access the central nervous system was estimated. Concerning metabolism, in which the cytochrome P450 isoforms have a key role, only the 5-phenylaminomethylenepyrimidine $\mathbf{7 d}$ was predicted to be a potential substrate of the important isoform CYP3A4. In general, it is expected that pyrimidines $\mathbf{2 c , d}, \mathbf{6 c - e}$ and $\mathbf{7 d}$ should accomplish most of the pharmacokinetic and toxicity criteria studied, however, the estimated maximum tolerated dose in humans and potential genotoxicity (Ames toxicity) for several compounds (Table S7) appeared to be the potential major problems. In fact, a mutagenic potential for the nitroaromatic derivatives $\mathbf{2 c - d}$, $6 \mathbf{e}$ and $7 \mathbf{d}$ is expected and therefore this point should be experimentally studied and the use of non-mutagenic bioisosteres should be considered.

\section{Conclusion}

A series of 1,3-trisubstituted barbiturates and thiobarbiturates substituted at the position 5 with benzylidene, benzyl, phenylcyanomethyl, acetyl, hydrazinylethylidene, phenylhydrazinylethylidene, phenylaminomethylene ylideneureas and the corresponding thioureas were synthesized, in moderate to 
excellent yields. In addition, the activity of these compounds as xanthine oxidase inhibitors, antioxidants as well as antibacterial and anti-proliferative agents was also evaluated. Some of the synthesized barbiturates were found to have potential for health-related applications, namely 1,3-dimethyl-5-[1-(2phenylhydrazinyl)ethylidene]pyrimidine-2,4,6(1H,3H,5H)-trione $\quad(\mathbf{6 c}) \quad$ and 1,3-dimethyl-5-[1-[2-(4nitrophenyl)hydrazinyl]ethylidene]pyrimidine-2,4,6(1H,3H,5H)-trione $(\mathbf{6 e})$ which showed moderate inhibition of xanthine oxidase ( $\mathrm{IC}_{50}$ values of 24.3 and $27.9 \mu \mathrm{M}$, respectively), and potent radical 2,2-diphenyl-1picrylhydrazyl scavenging activity ( $\mathrm{IC}_{50}$ values of 18.8 and $23.8 \mu \mathrm{M}$. respectively). Aditionally, 5-[1-(2phenylhydrazinyl)ethylidene]pyrimidine-2,4,6(1H,3H,5H)-trione (6d) was also highlighted as a relevant starting point for developing new radical scavengers. Interestingly, a selective antibacterial effect of 5hydrazinylethylidenepyrimidines 6c-e against Acinetobacter baumannii (12.5 to $25.0 \mu \mathrm{M}$ MIC values) was observed with concomitant low cytotoxicity in normal human dermal fibroblasts. On the other hand, compound 5-[[(2-chloro-4-nitrophenyl)amino]methylene]-2-thioxodihydropyrimidine-4,6(1H,5H)-dione (7d) presented a relevant and selective anti-proliferative effect against MCF-7 cells $\left(\mathrm{IC}_{50}=13.3 \mu \mathrm{M}\right)$. It should be noted that the presence of a conjugated carbon-carbon double bond in some of the studied barbituric and thiobarbituric acid derivatives may affect the observed biological activity due to possibility of the compounds to act as Michael acceptors [56-58]. According to in silico studies, all selected pyrimidines $\mathbf{2 c}, \mathbf{2 d}, \mathbf{6 c}-\mathbf{e}$ and $\mathbf{7 d}$ fulfil the Lipinski's rule of five as well as most of the pharmacokinetic and toxicity criteria determined for the different ADMET parameters. Therefore, a novel compound class with members bearing xanthine oxidase inhibitory activity, antioxidant effects as well as anti-proliferative action and the ability to inhibit the growth of Acinetobacter baumannii was revealed. However, future studies should be performed to improve not only the potency and selectivity of this family of compounds but also its pharmacokinetics.

\section{Experimental section}

\subsection{Chemistry}

All reagents were purchased from commercial suppliers and used without further purification. Reactions were monitored by thin-layer chromatography (TLC) on Merck-Nagel $60 \mathrm{G} / \mathrm{UV}_{254}(0.2 \mathrm{~mm})$ plates which 
were visualized by ultra-violet (UV) detection. Melting points were recorded on a Büchi B-540 melting point apparatus and are uncorrected. Infrared (IR) spectra were obtained with Thermo Fisher Scientific Nicolet iS10: smart iTR infrared spectrophotometer equipped with a diamond ATR crystal using OMNIC 8.2 software. The sample spectra were collected at room temperature in the $4000-400 \mathrm{~cm}^{-1}$ range by averaging 32 scans at a spectral resolution of $4 \mathrm{~cm}^{-1} .{ }^{1} \mathrm{H}-(400.13 \mathrm{MHz})$ and ${ }^{13} \mathrm{C}-(100.62 \mathrm{MHz}) \mathrm{NMR}$ spectra were performed on a Brüker Avance III $400 \mathrm{MHz}$ spectrometer and were processed with the software MestReNova 11.0.3 (trial). Chemical shifts were referenced to the residual solvent signal $\left(\mathrm{DMSO}-d_{6}: \delta_{\mathrm{H}}=2.50\right.$ and $\delta_{\mathrm{C}}=$ 39.52, or $\mathrm{CDCl}_{3}: \delta_{\mathrm{H}}=7.26$ and $\left.\delta_{\mathrm{C}}=77.16\right)$. The chemical shift $(\delta)$ values are given in parts per million (ppm), and the coupling constants $(J)$ are given in Hertz $(\mathrm{Hz})$. The multiplicity of the signals is reported as s (singlet), $\mathrm{d}$ (doublet), dd (doublet of doublets), dt (doublet of triplets), $\mathrm{t}$ (triplet), td (triplet of doublets) and $\mathrm{m}$ (multiplet). High resolution mass spectrometry (ESI-HRMS) was carried out on a Microanalysis QSTAR XL spectrometer by the microanalysis service (Salamanca, Spain). The ${ }^{1} \mathrm{H}$ NMR and ${ }^{13} \mathrm{C}$ NMR spectra of all compounds are presented on Supplementary Material.

4.1.1. 1,3-Diphenylthiourea [35]. To a stirred solution of phenylisothiocyanate $(1.00 \mathrm{mmol}$; $135 \mathrm{mg})$ in dichloromethane $(0.5 \mathrm{~mL})$ at room temperature, was added dropwise a solution of aniline $(1.00 \mathrm{mmol} ; 93 \mathrm{mg})$ in dichloromethane $(0.5 \mathrm{~mL})$. The reaction was followed by TLC (dichloromethane) and completed in 3 hours. The resulting suspension was filtered and washed with diethyl ether; Yield 95\%; white crystals; mp 142-144 ${ }^{\circ} \mathrm{C}$ (lit.[59] $\left.140-142{ }^{\circ} \mathrm{C}\right)$; IR $v_{\max }\left(\mathrm{cm}^{-1}\right) 3202,3053,1598,1526,1491,1449,1342,1313,1288,1242$, $1171,1069,1021,1003,933,756,694,642,629,610 ;{ }^{1} \mathrm{H}$ NMR $\left(400 \mathrm{MHz}, \mathrm{DMSO}-d_{6}\right) \delta(\mathrm{ppm}) 9.79$ (s, $2 \mathrm{H}, 2$ $\times \mathrm{NH}), 7.48\left(\mathrm{~d}, J=7.4 \mathrm{~Hz}, 4 \mathrm{H}, 2^{\prime}\right.$ and $\left.6^{\prime}-\mathrm{ArC} \underline{\mathrm{H}}\right), 7.33\left(\mathrm{t}, J=8.2\right.$ and $7.6 \mathrm{~Hz}, 4 \mathrm{H}, 3^{\prime}$ and $\left.5^{\prime}-\mathrm{ArC} \underline{\mathrm{H}}\right), 7.12(\mathrm{t}, J=$

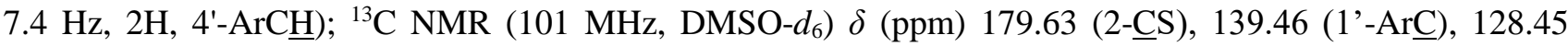
$(\mathrm{Ar} \underline{\mathrm{CH}}), 124.44$ (4'-Ar $\underline{\mathrm{CH}}), 123.66(\mathrm{Ar} \underline{\mathrm{CH}})$.

4.1.2. 1,3-Diphenylthiobarbituric acid (1a) [36]. A stirred solution of 1,3-diphenylthiourea (1.00 mmol; $228 \mathrm{mg})$, malonic acid $(1.30 \mathrm{mmol} ; 135 \mathrm{mg})$ and acetyl chloride (3.00 mmol; $235 \mathrm{mg} ; 214 \mu \mathrm{L})$ was heated at $60{ }^{\circ} \mathrm{C}$ for 30 minutes. The solid product obtained was ground into finer powder, filtered, washed with water and recrystallized from acetic acid; Yield 95\%; needle-like yellow crystals; mp 252-253 ${ }^{\circ} \mathrm{C}$ (lit [36] 258-259 $\left.{ }^{\circ} \mathrm{C}\right)$; IR $v_{\max }\left(\mathrm{cm}^{-1}\right) 3053,2895,1727,1707,1594,1490,1454,1381,1338,1260,1212,1165,1169,1037$, 
1003, 927, 747, 696, 687, 667; ${ }^{1} \mathrm{H}$ NMR $\left(400 \mathrm{MHz}, \mathrm{CDCl}_{3}\right) \delta(\mathrm{ppm}) 7.55(\mathrm{~m}, 6 \mathrm{H}, \mathrm{ArC} \underline{\mathrm{H}}), 7.21(\mathrm{~d}, J=7.3 \mathrm{~Hz}$,

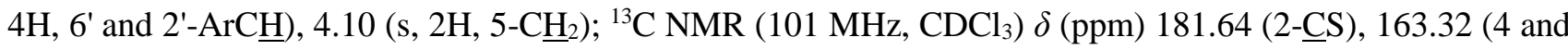

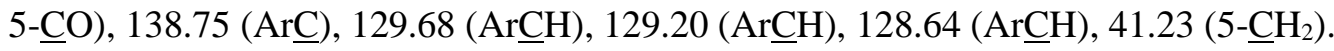

4.1.3. 5-Benzylidenepyrimidines 2a-e [37]. A stirred mixture of compound 1a-d $(1.00 \mathrm{mmol})$ and benzaldehyde $(1.00 \mathrm{mmol})$ in water $(5 \mathrm{~mL})$ was refluxed for 2 hours. After cooling, the formed product was filtered, washed with water, ethanol and diethyl ether to give the following 5-benzylidenepyrimidines:

4.1.3.1. 5-(2-Nitrobenzylidene)-1,3-diphenyl-2-thioxodihydropyrimidine-4,6(1H,5H)-dione $\quad(2 a)$. From 1,3-diphenylthiobarbituric acid (1a) and 2-nitrobenzaldehyde;Yield 90\%; pale orange solid. mp $235{ }^{\circ} \mathrm{C}$ dec. (lit [60] $232{ }^{\circ} \mathrm{C}$ ); IR $v_{\max }\left(\mathrm{cm}^{-1}\right) 3032,1717,1691,1624,1607,1591,1520,1486,1353,1325,1265,1189$, $1156,788,781,752,722,692 ;{ }^{1} \mathrm{H}$ NMR $\left(400 \mathrm{MHz}, \mathrm{DMSO}-d_{6}\right) \delta(\mathrm{ppm}) 8.80(\mathrm{~s}, 1 \mathrm{H}, 5-\mathrm{CC} \underline{\mathrm{H}}), 8.19(\mathrm{~d}, J=8.2$ $\mathrm{Hz}, 1 \mathrm{H}), 7.71(\mathrm{t}, J=7.5 \mathrm{~Hz}, 1 \mathrm{H}), 7.59(\mathrm{t}, J=7.9 \mathrm{~Hz}, 2 \mathrm{H}), 7.45(\mathrm{t}, J=7.6 \mathrm{~Hz}, 2 \mathrm{H}), 7.40-7.28(\mathrm{~m}, 6 \mathrm{H}), 7.20$

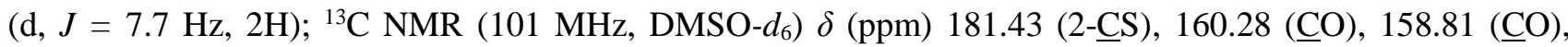

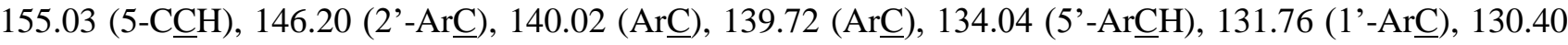

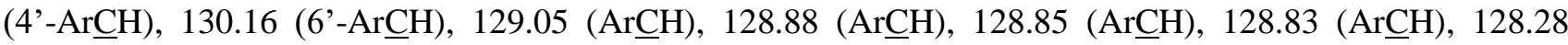

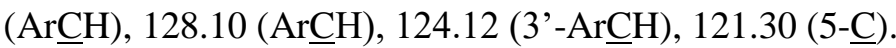

4.1.3.2. 5-(2-Nitrobenzylidene)-2-thioxodihydropyrimidine-4,6(1H,5H)-dione (2b). From thiobarbituric acid (1b) and 2-nitrobenzaldehyde; Yield 90\%; pale yellow solid; mp 239-241 ${ }^{\circ} \mathrm{C}$ (lit [61] 246-250 ${ }^{\circ} \mathrm{C}$ ); IR $v_{\max }\left(\mathrm{cm}^{-1}\right) 3255,3156,2876,1718,1692,1626,1540,1513,1439,1351,1288,1203,1141,785,759,732 ;{ }^{1} \mathrm{H}$ NMR (400 MHz, DMSO- $\left.d_{6}\right) \delta(\mathrm{ppm}) 12.56(\mathrm{~s}, 1 \mathrm{H}, \mathrm{N} \underline{\mathrm{H}}), 12.33(\mathrm{~s}, 1 \mathrm{H}, \mathrm{N} \underline{\mathrm{H}}), 8.63$ (s, 1H, 5-CCㅂ), 8.24 (dd, $J$ $=8.3$ and $\left.1.0 \mathrm{~Hz}, 1 \mathrm{H}, 3^{\prime}-\mathrm{ArCH}\right), 7.80\left(\mathrm{td}, J=7.6\right.$ and $\left.1.1 \mathrm{~Hz}, 1 \mathrm{H}, 5^{\prime}-\mathrm{ArC} \underline{\mathrm{H}}\right), 7.72-7.66\left(\mathrm{~m}, 1 \mathrm{H}, 4^{\prime}-\mathrm{ArC} \underline{\mathrm{H}}\right)$, $7.62\left(\mathrm{dt}, J=7.7\right.$ and $\left.1.2 \mathrm{~Hz}, 1 \mathrm{H}, 6{ }^{\prime}-\mathrm{ArC} \underline{\mathrm{H}}\right) ;{ }^{13} \mathrm{C}$ NMR (101 MHz, DMSO- $\left.d_{6}\right) \delta$ (ppm) 179.05 (2-CS $), 160.63$

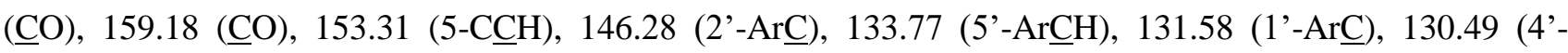

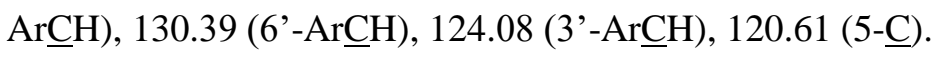

4.1.3.3. 1,3-Dimethyl-5-(2-nitrobenzylidene)pyrimidine-2,4,6(1H,3H,5H)-trione $\quad(\mathbf{2 c}) . \quad$ From $\quad$ 1,3dimethylbarbituric acid (1c) and 2-nitrobenzaldehyde; Yield 97\%; white solid; mp 158-159 ${ }^{\circ} \mathrm{C}$ (lit [62] 159$\left.161{ }^{\circ} \mathrm{C}\right) ; \mathrm{IR} v_{\max }\left(\mathrm{cm}^{-1}\right) 3028,2950,1663,1603,1518,1457,1415,1377,1342,1323,1161,1092,1057,787$, 754, 737, 692; ${ }^{1} \mathrm{H}$ NMR (400 MHz, DMSO- $\left.d_{6}\right) \delta(\mathrm{ppm}) 8.71(\mathrm{~s}, 1 \mathrm{H}, 5-\mathrm{CC} \underline{\mathrm{H}}), 8.26$ (dd, $J=8.3$ and $1.2 \mathrm{~Hz}$, 
$\left.1 \mathrm{H}, 3^{\prime}-\mathrm{ArC} \underline{\mathrm{H}}\right), 7.80$ (td, $J=7.6$ and $\left.1.3 \mathrm{~Hz}, 1 \mathrm{H}, 5^{\prime}-\mathrm{ArC} \underline{\mathrm{H}}\right), 7.69\left(\mathrm{t}, J=7.7 \mathrm{~Hz}, 1 \mathrm{H}, 4^{\prime}-\mathrm{ArC} \underline{\mathrm{H}}\right), 7.53(\mathrm{~d}, J=7.8$ $\mathrm{Hz}, 1 \mathrm{H}, 6$ ' $-\mathrm{ArC} \underline{\mathrm{H}}), 3.25$ (s, 3H, NC$\left.\underline{H}_{3}\right), 3.06\left(\mathrm{~s}, 3 \mathrm{H}, \mathrm{NCH}_{3}\right) ;{ }^{13} \mathrm{C} \mathrm{NMR}\left(101 \mathrm{MHz}, \mathrm{DMSO}-d_{6}\right) \delta(\mathrm{ppm}) 161.20$

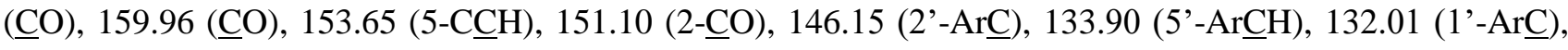

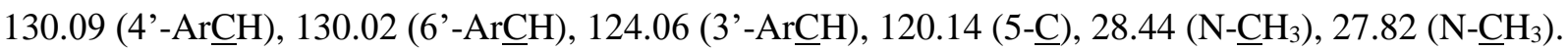

4.1.3.4. 5-(2-Nitrobenzylidene)pyrimidine-2,4,6(1H,3H,5H)-trione (2d). From barbituric acid (1d) and 2nitrobenzaldehyde; Yield 97\%; white solid; mp 274-275 ${ }^{\circ} \mathrm{C}$ (lit [61] 274-276 ${ }^{\circ} \mathrm{C}$ ); IR $v_{\max }\left(\mathrm{cm}^{-1}\right) 3230,3070$, $2849,1739,1676,1597,1516,1434,1368,1341,1312,1218,848,791,803,735,710 ;{ }^{1} \mathrm{H}$ NMR (400 MHz, DMSO- $\left.d_{6}\right) \delta(\mathrm{ppm}) 11.49(\mathrm{~s}, 1 \mathrm{H}, \mathrm{N} \underline{\mathrm{H}}), 11.24(\mathrm{~s}, 1 \mathrm{H}, \mathrm{N} \underline{\mathrm{H}}), 8.60(\mathrm{~s}, 1 \mathrm{H}, 5-\mathrm{CC} \underline{\mathrm{H}}), 8.23\left(\mathrm{~d}, J=7.9 \mathrm{~Hz}, 1 \mathrm{H}, 3^{\prime}-\right.$ $\operatorname{ArC} \underline{\mathrm{H}}), 7.79\left(\mathrm{t}, J=7.4 \mathrm{~Hz}, 1 \mathrm{H}, 5^{\prime}-\mathrm{ArC} \underline{\mathrm{H}}\right), 7.68\left(\mathrm{t}, J=7.7 \mathrm{~Hz}, 1 \mathrm{H}, 4^{\prime}-\mathrm{ArC} \underline{\mathrm{H}}\right), 7.57\left(\mathrm{~d}, J=7.7 \mathrm{~Hz}, 1 \mathrm{H}, 6^{\prime}-\right.$

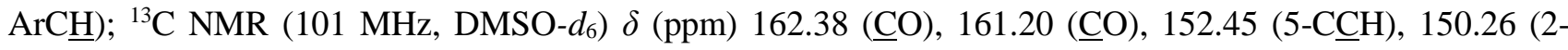

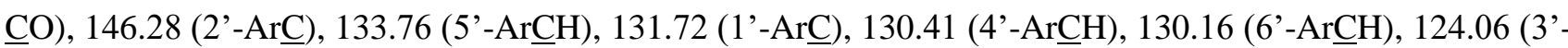
$\operatorname{Ar} \underline{\mathrm{CH}}), 120.54$ (5-ㅡ).

4.1.3.5. 5-(4-Methoxybenzylidene)pyrimidine-2,4,6(1H,3H,5H)-trione (2e). From barbituric acid (1d) and 4-methoxybenzaldehyde; Yield 92\%; yellow solid; mp 286-289 ${ }^{\circ} \mathrm{C}$ (lit [37] 297-300 ${ }^{\circ} \mathrm{C}$ ); IR $v_{\max }\left(\mathrm{cm}^{-1}\right) 3046$, $2838,1745,1698,1651,1601,1567,1532,1509,1444,1431,1393,1355,1316,1266,1215,1179,1117$, 1041, 1001, 834, 790, 752, 691, 631; ${ }^{1} \mathrm{H}$ NMR (400 MHz, DMSO- $\left.d_{6}\right) \delta(\mathrm{ppm}) 11.29(\mathrm{~s}, 1 \mathrm{H}, \mathrm{NH}), 11.17$ (s,

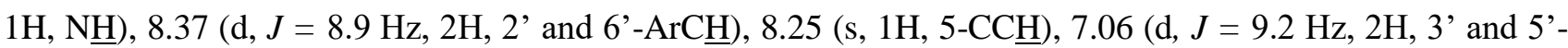

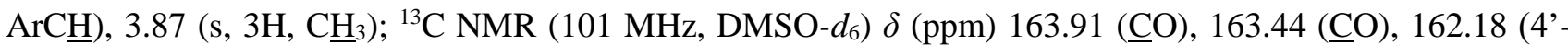

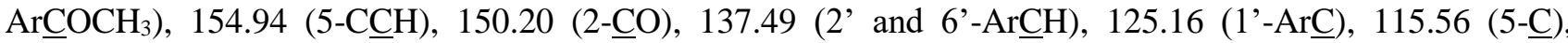
113.95 (3' and 5'-ArCH$), 55.70\left(\mathrm{O}-\underline{\mathrm{CH}}{ }_{3}\right)$.

4.1.4. 5-(4-Methoxybenzyl)pyrimidine-2,4,6(1H,3H,5H)-trione (3) [38]. To a stirred solution of 5-(4methoxybenzylidene)pyrimidine-2,4,6(1H,3H,5H)-trione $(\mathbf{2 e})(1.00 \mathrm{mmol})$ in ethanol $(30 \mathrm{~mL})$, were added little portions of sodium borohydride $(3.00 \mathrm{mmol})$. The reaction was followed by TLC (ethyl acetate) and completed after 4 hours at room temperature. The solvent was evaporated to dryness, and water $(20 \mathrm{~mL})$ was added with the formation of a suspension, which was acidified with $1 \mathrm{M}$ hydrochloric acid until $\mathrm{pH} 5$. The formed solid was filtered and recrystallized from methanol. Yield 41\%; white solid; mp 194-195 ${ }^{\circ} \mathrm{C}$ (lit. [63] $\left.205-210{ }^{\circ} \mathrm{C}\right) ; \mathrm{IR} v_{\max }\left(\mathrm{cm}^{-1}\right) 3224,2966,2929,2835,1743,1669,1608,1566,1504,1421,1390,1324,1299$, 
$1273,1249,1175,1113,1093,1033,835,797,779,751,688,668 ;{ }^{1} \mathrm{H}$ NMR (400 MHz, DMSO- $\left.d_{6}\right) \delta(\mathrm{ppm})$

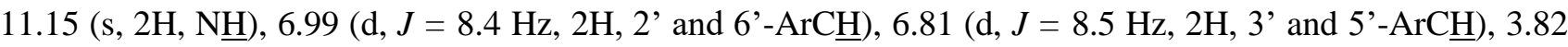
$(\mathrm{t}, J=4.8 \mathrm{~Hz}, 1 \mathrm{H}, 5-\mathrm{C} \underline{\mathrm{H}}), 3.70\left(\mathrm{~s}, 3 \mathrm{H}, \underline{\mathrm{C}}_{3}\right), 3.19\left(\mathrm{~d}, J=4.8 \mathrm{~Hz}, 2 \mathrm{H}, 5-\mathrm{CC}_{2}\right) ;{ }^{13} \mathrm{C}$ NMR $(101 \mathrm{MHz}, \mathrm{DMSO}-$

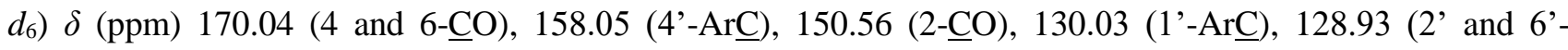

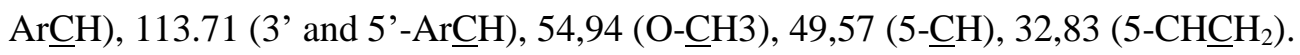

4.1.5. 5-Phenylcyanomethylpyrimidines 4a-b [39]. A stirred suspension of compound $\mathbf{1 b}-\mathbf{b}$ (1.00 mmol) and 4-bromobenzaldehyde $(1.00 \mathrm{mmol})$ in water $(5 \mathrm{~mL})$ was refluxed for 2 hours. After cooling, sodium cyanide $(1.00 \mathrm{mmol})$ was added and the resulting mixture was stirred at $70{ }^{\circ} \mathrm{C}$. The reaction was followed by TLC (dichloromethane/methanol 20\%) and completed after 1 hour. The reaction mixture was evaporated to dryness and the obtained solid was dissolved in an equimixture of methanol and ethyl acetate. The product formed after partial evaporation of the solvent was filtered and washed with diethyl ether to give the following 5-phenylcyanomethylpyrimidines:

\subsubsection{Sodium 5-[(4-bromophenyl)(cyano)methyl]-6-oxo-2-thioxo-1,2,3,6-tetrahydropyrimidine-4-olate}

(4a). From thiobarbituric acid (1b); Yield 67\%; white solid; mp $310{ }^{\circ} \mathrm{C} \mathrm{dec}$.; IR $v_{\max }\left(\mathrm{cm}^{-1}\right)$ 3092, 2881, 2245, $1592,1525,1485,1418,1300,1173,1010,789 ;{ }^{1} \mathrm{H}$ NMR (400 MHz, DMSO- $\left.d_{6}\right) \delta(\mathrm{ppm}) 10.72(\mathrm{~s}, 2 \mathrm{H}, 2 \times$ $\mathrm{N} \underline{\mathrm{H}}), 7.47(\mathrm{~d}, J=8.1 \mathrm{~Hz}, 2 \mathrm{H}, 2 \times \mathrm{ArCH}), 7.31(\mathrm{~d}, J=7.9 \mathrm{~Hz}, 2 \times \mathrm{ArC} \underline{\mathrm{H}}, 2 \mathrm{H}), 5.24(\mathrm{~s}, 1 \mathrm{H}, 5-\mathrm{CC} \underline{\mathrm{H}}) ;{ }^{13} \mathrm{C} \mathrm{NMR}$

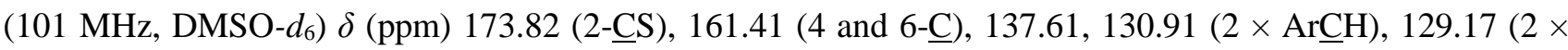

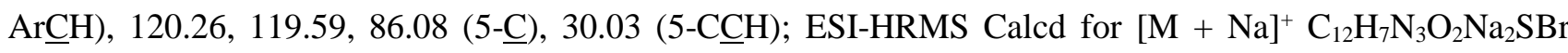
381.9232 , found 381.9223 .

\subsubsection{Sodium}

5-[(4-bromophenyl)(cyano)methyl]-1,3-dimethyl-2,6-dioxo-1,2,3,6-

tetrahydropyrimidine-4-olate (4b) From 1,3-dimethylbarbituric acid (1c); Yield 77\%; white solid; mp 273 ${ }^{\circ} \mathrm{C}$ dec.; IR $v_{\max }\left(\mathrm{cm}^{-1}\right)$ 3445, 2951, $2247(\mathrm{CN}), 1668(\mathrm{C}=\mathrm{O}), 1583(\mathrm{C}=\mathrm{C}), 1442,1317,1010,776,{ }^{1} \mathrm{H}$ NMR $\left(400 \mathrm{MHz}, \mathrm{DMSO}-d_{6}\right) \delta 7.45(\mathrm{~d}, J=8.5 \mathrm{~Hz}, 2 \mathrm{H}, 2 \times \mathrm{ArC} \underline{\mathrm{H}}), 7.31(\mathrm{~d}, J=8.2 \mathrm{~Hz}, 2 \mathrm{H}, 2 \times \operatorname{ArC} \underline{\mathrm{H}}), 5.35(\mathrm{~s}, 1 \mathrm{H}$, 5-CC프), $3.04\left(\mathrm{~s}, 6 \mathrm{H}, 2 \times \mathrm{NC}_{3}\right) ;{ }^{13} \mathrm{C} \mathrm{NMR}\left(101 \mathrm{MHz}, \mathrm{DMSO}-d_{6}\right) \delta 161.10$ (4 and 6-C), 152.75 (2-CO),

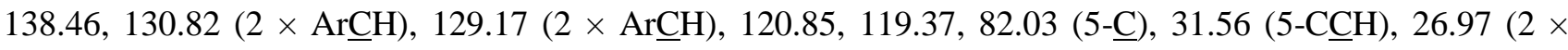
$\mathrm{NCH}_{3}$ ); ESI-HRMS Calcd for $[\mathrm{M}+\mathrm{Na}]^{+} \mathrm{C}_{14} \mathrm{H}_{11} \mathrm{~N}_{3} \mathrm{O}_{3} \mathrm{Na}_{2} \mathrm{Br}$ 393.9774, found 393.9760. 
4.1.6. 5-Acetylpyrimidines (5a-c) [40]. A solution of compound 1a or 1c-d (1.00 mmol) and concentrated sulfuric acid $(0.100 \mathrm{mmol})$ was refluxed in acetic anhydride $(1.00 \mathrm{mmol})$ for 1 hour. The reaction was followed by TLC (dichloromethane/5\% methanol). The reaction mixture was concentrated to half of the initial volume and poured onto ice. The formed solid was isolated, washed with hot water, dried and recrystallized from ethanol/water (2:1) to give the following 5-acetylpyrimidines:

\subsubsection{5-Acetyl-1,3-diphenyl-2-thioxodihydropyrimidine-4,6(1H,5H)-dione $\quad(5 \mathbf{5}) . \quad$ From $\quad 1,3-$} diphenylthiobarbituric acid (1a); Yield 65\%; brown needle crystals; mp 256-257 ${ }^{\circ} \mathrm{C}$ (lit [36] 258-259 ${ }^{\circ} \mathrm{C}$ ). IR $v_{\max }\left(\mathrm{cm}^{-1}\right) 3051,3014,1701,1635,1595,1557,1488,1452,1414,1364,1320,1271,1240,1187,1161,1094$, $1004,967,914,828,781,746,730,639,652,612 ;{ }^{1} \mathrm{H}$ NMR $\left(400 \mathrm{MHz}, \mathrm{DMSO}-d_{6}\right) \delta(\mathrm{ppm}) 7.48(\mathrm{t}, J=7.4$ $\mathrm{Hz}, 4 \mathrm{H}, 3^{\prime}$ and 5'-ArC $\left.\underline{\mathrm{H}}\right), 7.39$ (t, $\left.J=7.7 \mathrm{~Hz}, 2 \mathrm{H}, 4^{\prime}-\mathrm{ArC} \underline{\mathrm{H}}\right), 7.30$ (d, $J=7.7 \mathrm{~Hz}, 4 \mathrm{H}, 2^{\prime}$ and 6'-ArC $\left.\underline{\mathrm{H}}\right), 2.66$ (s, 3H, 5-CCC $\left.\underline{H}_{3}\right) ;{ }^{13} \mathrm{C}$ NMR (101 MHz, DMSO-d $) \delta$ (ppm) $196.90\left(5-\mathrm{CCCH}_{3}\right), 179.97$ (2-CS), 139.68 (1'-

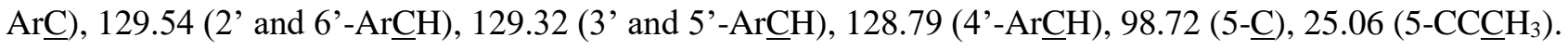

4.1.6.2. 5-Acetyl-1,3-dimethylpyrimidine-2,4,6(1H,3H,5H)-trione (5b). From 1,3-dimethylbarbituric acid (1c); Yield 45\%; golden solid; mp 91-92 ${ }^{\circ} \mathrm{C}$ (lit [64] 96.5-98.5 $\left.{ }^{\circ} \mathrm{C}\right)$; IR $v_{\max }\left(\mathrm{cm}^{-1}\right) 3011,2963,1721(\mathrm{C}=\mathrm{O})$, $1656(\mathrm{C}=\mathrm{O}), 1557,1494,1455,1364,1337,1274,1221,1164,1017,988,876,787,754,676 ;{ }^{1} \mathrm{H}$ NMR $(400$ MHz, DMSO- $\left.d_{6}\right) \delta(\mathrm{ppm}) 3.18\left(\mathrm{~s}, 6 \mathrm{H}, 2 \times \mathrm{NC}_{3}\right), 2.63\left(\mathrm{~s}, 3 \mathrm{H}, 5-\mathrm{CCC}_{3}\right) ;{ }^{13} \mathrm{C} \mathrm{NMR}\left(101 \mathrm{MHz}, \mathrm{DMSO}-d_{6}\right) \delta$

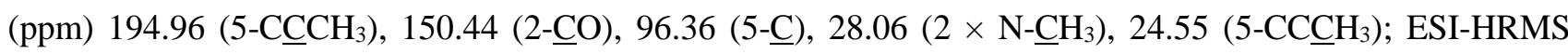
Calcd for $[\mathrm{M}+\mathrm{H}]^{+} \mathrm{C}_{8} \mathrm{H}_{11} \mathrm{~N}_{2} \mathrm{O}_{4}$ 199.0713, found 199.0726.

4.1.6.3. 5-Acetylpyrimidine-2,4,6(1H,3H,5H)-trione (5c). From barbituric acid (1d); Yield 83\%; brown solid; mp 305-307 ${ }^{\circ} \mathrm{C}$ (lit [65] 296-300 ${ }^{\circ} \mathrm{C}$ ); IR $v_{\max }\left(\mathrm{cm}^{-1}\right)$ 3280, 3202, 3115, 3029, 2776, 1779, 1732, 1688, $1625,1515,1463,1380,1249,1207,1114,1061,1028,966,800,741,650 ;{ }^{1} \mathrm{H}$ NMR $\left(400 \mathrm{MHz}\right.$ DMSO- $\left.d_{6}\right) \delta$ (ppm) $11.78(\mathrm{~s}, 1 \mathrm{H}, \mathrm{N} \underline{\mathrm{H}}), 11.04(\mathrm{~s}, 1 \mathrm{H}, \mathrm{N} \underline{\mathrm{H}}), 2.58\left(\mathrm{~s}, 3 \mathrm{H}, 5-\mathrm{CCC}_{3}\right) ;{ }^{13} \mathrm{C} \mathrm{NMR}\left(101 \mathrm{MHz}, \mathrm{DMSO}-d_{6}\right) \delta$

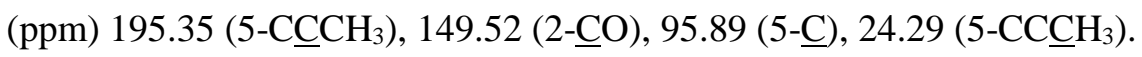

4.1.7. 5-Hydrazinylethylidenepyrimidines (6a-g) [40]. A stirred suspension of 5-acetylpyrimidine 5a-c $(1.00 \mathrm{mmol})$ and the appropriate hydrazine $(1.00 \mathrm{mmol})$ in methanol $(20 \mathrm{~mL})$ was refluxed overnight. The formed solid was filtrated, washed with hot water and methanol to give the following 5hydrazinylethylidenepyrimidines: 
From 5-acetyl-1,3-diphenyl-2-thioxodihydropyrimidine-4,6(1H,5H)-dione (5a) and hydrazine hydrate; Yield $88 \%$; brown solid; $\operatorname{mp} 242-243{ }^{\circ} \mathrm{C}$; IR $v_{\max }\left(\mathrm{cm}^{-1}\right) 3331,3246,3047,1662,1620,1593,1552,1489,1454$, $1410,1363,1355,1311,1298,1284,1175,1122,1066,1021,977,817,800,772,752,720,692,607 ;{ }^{1} \mathrm{H}$

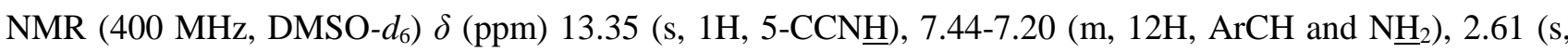
3H, 5-CCC $\left.\underline{H}_{3}\right) ;{ }^{13} \mathrm{C}$ NMR (101 MHz, DMSO-d $) \delta(\mathrm{ppm}) 178.47$ (2-도), 166.18 (5- $\left.\mathrm{CCCH}_{3}\right), 162.03$ (4 and 6-

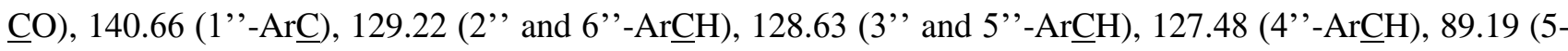
C), 15.91 (5-CCㅡㅐ $\left.{ }_{3}\right)$; ESI-HRMS Calcd for $[\mathrm{M}+\mathrm{H}]^{+} \mathrm{C}_{18} \mathrm{H}_{17} \mathrm{~N}_{4} \mathrm{O}_{2} \mathrm{~S} 353.1067$, found 353.1069.

4.1.7.2. 5-(1-Hydrazinylethylidene)pyrimidine-2,4,6(1H,3H,5H)-trione $(\mathbf{6 b})$. From 5-acetylpyrimidine2,4,6(1H,3H,5H)-trione (5c) and hydrazine hydrate; Yield 86\%; yellow solid; mp $300{ }^{\circ} \mathrm{C} \mathrm{dec}$.; IR $v_{\max }\left(\mathrm{cm}^{-1}\right)$ $3344,3246,3004,1639,1647,1609,1573,1435,1374,1346,1262,1242,1144,1093,1037,977,923,872$,

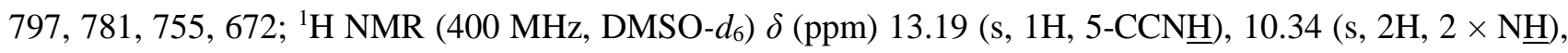
$5.55\left(\mathrm{~s}, 2 \mathrm{H}, \mathrm{N}_{2}\right), 2,61\left(\mathrm{~s}, 3 \mathrm{H}, 5-\mathrm{CCC}_{3}\right) ;{ }^{13} \mathrm{C} \mathrm{NMR}\left(101 \mathrm{MHz}, \mathrm{DMSO}-d_{6}\right) \delta(\mathrm{ppm}) 168.35\left(5-\mathrm{CCCH}_{3}\right)$,

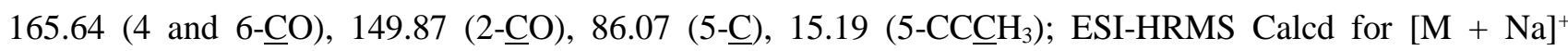
$\mathrm{C}_{6} \mathrm{H}_{8} \mathrm{~N}_{4} \mathrm{O}_{3} \mathrm{Na}$ 207.0489, found 207.0493.

4.1.7.3. 1,3-Dimethyl-5-(1-(2-phenylhydrazinyl)ethylidene)pyrimidine-2,4,6(1H,3H,5H)-trione $(6 \mathbf{c})$. From 5-acetyl-1,3-dimethylpyrimidine-2,4,6(1H,3H,5H)-trione (5b) and phenylhydrazine; Yield 50\%; white needle-like crystals; $\mathrm{mp} 182-184{ }^{\circ} \mathrm{C}$; IR $v_{\max }\left(\mathrm{cm}^{-1}\right) 3250,3111,2997,2950,1704,1672,1600,1561,1459$, $1415,1374,1355,1306,1252,1214,1157,1123,1053,1026,971,816,736,749,690,641 ;{ }^{1} \mathrm{H}$ NMR $(400$ MHz, DMSO- $\left.d_{6}\right) \delta(\mathrm{ppm}) 13.36$ (s, 1H, 5-CCNH), 8.63 (s, 1H, 1'-ArCNH), 7.27 (t, $J=7.8 \mathrm{~Hz}, 2 \mathrm{H}, 3^{\prime}$ and 5'$\operatorname{ArC} \underline{H}), 6.89\left(\mathrm{t}, J=7.4 \mathrm{~Hz}, 1 \mathrm{H}, 4^{\prime}-\mathrm{ArCH}\right), 6.77\left(\mathrm{~d}, J=7.4 \mathrm{~Hz}, 2 \mathrm{H}, 2^{\prime}\right.$ and 6'-ArC $\left.\underline{\mathrm{H}}\right), 3.17\left(\mathrm{~s}, 6 \mathrm{H}, 2 \times \mathrm{NCH}_{3}\right)$, $2.70\left(\mathrm{~s}, 3 \mathrm{H}, 5-\mathrm{CCC}_{3}\right) ;{ }^{13} \mathrm{C}$ NMR (101 MHz, DMSO-d $\left.)\right) \delta(\mathrm{ppm}) 174.83\left(5-\mathrm{CCCH}_{3}\right) 150.66$ (2-으), 146.43

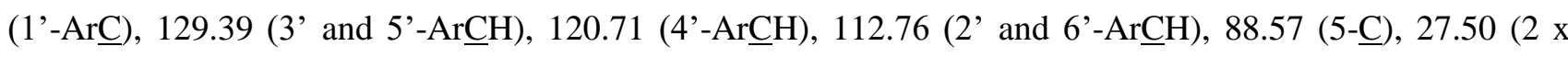
$\left.\mathrm{NCH}_{3}\right), 16.28$ (5-CCCH 3$)$; ESI-HRMS Calcd for $[\mathrm{M}+\mathrm{H}]^{+} \mathrm{C}_{14} \mathrm{H}_{17} \mathrm{~N}_{4} \mathrm{O}_{3} 289.1295$, found 289.1302. acetylpyrimidine-2,4,6(1H,3H,5H)-trione (5c) and phenylhydrazine; Yield 92\%; dark white solid; mp 307-310 ${ }^{\circ} \mathrm{C}$; IR $v_{\max }\left(\mathrm{cm}^{-1}\right) 3267,3173,3108,3064,3010,2828,1712,1662,1628,1601,1567,1498,1458,1429$, 
$1407,1376,1359,1306,1255,1241,1181,1152,1048,832,799,772,746,691,651 ;{ }^{1} \mathrm{H}$ NMR (400 MHz, DMSO- $\left.d_{6}\right) \delta(\mathrm{ppm}) 13.26(\mathrm{~s}, 1 \mathrm{H}, 5-\mathrm{CCN} \underline{\mathrm{H}}), 10.65(\mathrm{~s}, 2 \mathrm{H}, 2 \times \mathrm{N} \underline{\mathrm{H}}), 8.54\left(\mathrm{~s}, 1 \mathrm{H}, 1{ }^{\prime}-\mathrm{ArCN} \underline{\mathrm{H}}\right), 7.26(\mathrm{t}, J=8.0$ $\mathrm{Hz}, 2 \mathrm{H}, 3^{\prime}$ and 5' $\left.-\mathrm{ArC} \underline{\mathrm{H}}\right), 6.89$ (t, $\left.J=7.8 \mathrm{~Hz}, 1 \mathrm{H}, 4^{\prime}-\mathrm{ArC} \underline{\mathrm{H}}\right), 6.76\left(\mathrm{~d}, J=7.3 \mathrm{~Hz}, 2 \mathrm{H}, 2^{\prime}\right.$ and 6'-ArC $\left.\underline{\mathrm{H}}\right), 2.67$ (s, 3H, 5-CCC $\left.\underline{H}_{3}\right) ;{ }^{13} \mathrm{C}$ NMR (101 MHz, DMSO-d $d_{6} \delta(\mathrm{ppm}) 174.87\left(5-\mathrm{CCCH}_{3}\right), 149.72$ (2- $\left.\underline{\mathrm{CO}}\right), 146.59$ (1'-

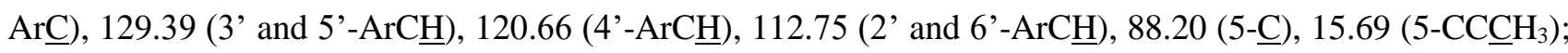
ESI-HRMS Calcd for $[\mathrm{M}+\mathrm{H}]^{+} \mathrm{C}_{12} \mathrm{H}_{13} \mathrm{~N}_{4} \mathrm{O}_{3} 261.0982$, found 261.0982 .

\subsubsection{1,3-Dimethyl-5-[1-[2-(4-nitrophenyl)hydrazinyl]ethylidene]pyrimidine-2,4,6(1H,3H,5H)-trione}

(6e). From 5-acetyl-1,3-dimethylpyrimidine-2,4,6(1H,3H,5H)-trione (5b) and 4-nitrophenylhydrazine; Yield 67\%; brick-colored solid; mp 228-232 ${ }^{\circ} \mathrm{C}$; IR $v_{\max }\left(\mathrm{cm}^{-1}\right) 3327,3254,2948,2602,2432,2160,1706,1612$, $1524,1498,1455,1416,1376,1357,1321,1299,1270,1202,1176,1104,971,836,797,794,690,658 ;{ }^{1} \mathrm{H}$ NMR (400 MHz, DMSO- $\left.d_{6}\right) \delta(\mathrm{ppm}) 13.29(\mathrm{~s}, 1 \mathrm{H}, 5-\mathrm{CCNH}), 9.76\left(\mathrm{~s}, 1 \mathrm{H}, 1^{\prime}-\mathrm{ArCN} \underline{\mathrm{H}}\right), 8.16$ (d, $J=9.8 \mathrm{~Hz}$,

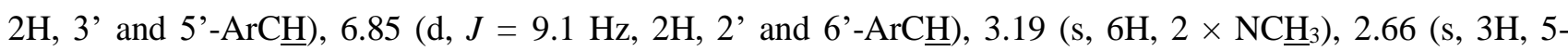

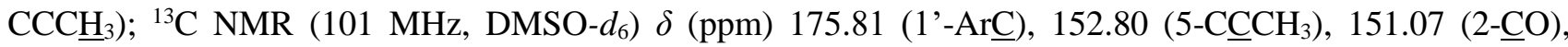

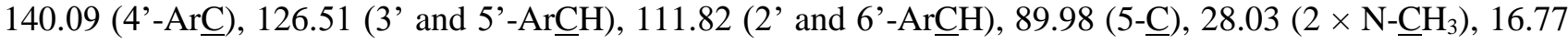
(5-CCCH 3 ); ESI-HRMS Calcd for $[\mathrm{M}+\mathrm{H}]^{+} \mathrm{C}_{14} \mathrm{H}_{16} \mathrm{~N}_{5} \mathrm{O}_{5} 334.1146$, found 334.1148.

\subsubsection{5-[1-[2-(2,4-Dinitrophenyl)hydrazinyl]ethylidene]-1,3-dimethylpyrimidine-2,4,6(1H,3H,5H)-}

trione (6f). From 5-acetyl-1,3-dimethylpyrimidine-2,4,6(1H,3H,5H)-trione $\quad(\mathbf{5 b}) \quad$ and $\quad 2,4-$ dinitrophenylhydrazine; Yield 83\%; mp 245-247 ${ }^{\circ} \mathrm{C}$; IR $v_{\max }\left(\mathrm{cm}^{-1}\right) 3362,3093,2952,1705,1650,1615$, $1594,1558,1538,1509,1455,1360,1332,1315,1275,1237,1207,1157,1142,1114,1060,972,923,850$, 817, 754, 744, 715, 651, 620; ${ }^{\mathrm{H}} \mathrm{NMR}\left(400 \mathrm{MHz}, \mathrm{DMSO}-d_{6}\right) \delta(\mathrm{ppm}) 13.25$ (s, 1H, 5-CCN 1'-ArCN $\underline{\mathrm{H}}), 8.89\left(\mathrm{~d}, J=2.7 \mathrm{~Hz}, 1 \mathrm{H}, 3^{\prime}-\mathrm{ArC} \underline{\mathrm{H}}\right), 8.38\left(\mathrm{dd}, J=9.4\right.$ and $\left.2.7 \mathrm{~Hz}, 1 \mathrm{H}, 5^{\prime}-\mathrm{ArC} \underline{\mathrm{H}}\right), 7.17(\mathrm{~d}, J=9.5$ $\mathrm{Hz}, 1 \mathrm{H}, 6$ ' $-\mathrm{ArC} \underline{\mathrm{H}}), 3.20$ (s, 6H, $\left.2 \times \mathrm{NC}_{3}\right), 2.65\left(\mathrm{~s}, 3 \mathrm{H}, 5-\mathrm{CCC}_{3}\right) ;{ }^{13} \mathrm{C} \mathrm{NMR}\left(101 \mathrm{MHz}, \mathrm{DMSO}-d_{6}\right) \delta(\mathrm{ppm})$

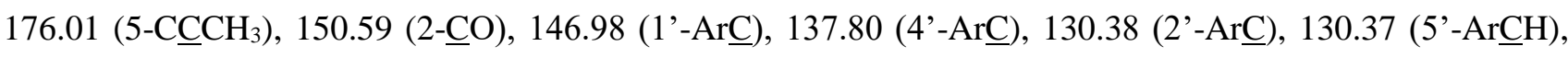

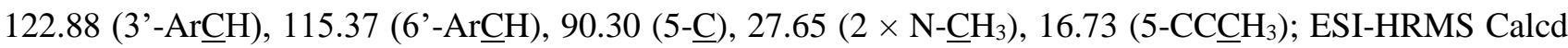
for $[\mathrm{M}+\mathrm{Na}]^{+} \mathrm{C}_{12} \mathrm{H}_{10} \mathrm{~N}_{6} \mathrm{O}_{7} \mathrm{Na} 373.0503$, found 373.0498 .

4.1.7.7. 5-[1-[2-(2,4-Dinitrophenyl)hydrazinyl]ethylidene]pyrimidine-2,4,6(1H,3H,5H)-trione $(6 \mathrm{~g})$. From 5-acetylpyrimidine-2,4,6(1H,3H,5H)-trione (5c) and 2,4-dinitrophenylhydrazine; Yield 87\%; mp $342{ }^{\circ} \mathrm{C}$ dec.; 
IR $v_{\max }\left(\mathrm{cm}^{-1}\right) 3325,3231,3094,3033,2797,1710,1682,1634,1616,1591,1505,1455,1334,1313,1272$, $1234,1175,1143,1127,1059,1035,925,912,805,765,740,714,661,634 ;{ }^{1} \mathrm{H}$ NMR (400 MHz, DMSO-d $)_{6}$

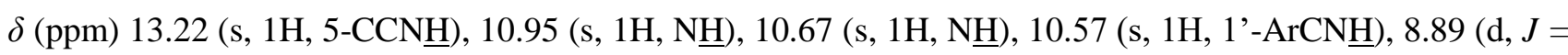
$\left.2.6 \mathrm{~Hz}, 1 \mathrm{H}, 3^{\prime}-\mathrm{ArC} \underline{\mathrm{H}}\right), 8.38$ (dd, $J=9.5$ and $\left.2.6 \mathrm{~Hz}, 1 \mathrm{H}, 5^{\prime}-\mathrm{ArC} \underline{\mathrm{H}}\right), 7.20\left(\mathrm{~d}, J=9.5 \mathrm{~Hz}, 1 \mathrm{H}, 6^{\prime}-\mathrm{ArC} \underline{\mathrm{H}}\right), 2.62$ (s, 3H, 5-CCC $\left.\underline{H}_{3}\right) ;{ }^{13} \mathrm{C}$ NMR (101 MHz, DMSO-d $d_{6} \delta(\mathrm{ppm}) 175.82\left(5-\mathrm{C}^{-} \mathrm{CH}_{3}\right), 149.63$ (2-으), 147.10 (1'-

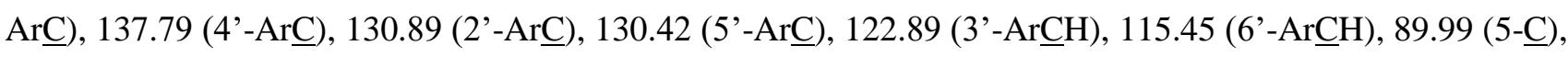
16.08 (5-CCㅡㅐ $\left.{ }_{3}\right)$; ESI-HRMS Calcd for $[\mathrm{M}+\mathrm{H}]^{+} \mathrm{C}_{14} \mathrm{H}_{15} \mathrm{~N}_{6} \mathrm{O}_{7} 379.0997$, found 379.0992 .

4.1.8. 5-Phenylaminomethylenepyrimidines (7a-j). Obtained from the corresponding compounds 1a-c and anilines by the reaction conditions A or B adapted from the literature [27]. All products were isolated by hot filtration and washed with hot ethanol and diethyl ether to give the following 5phenylaminomethylenepyrimidines.

Reaction conditions A: A stirred mixture of compound 1b-c (1.00 mmol) and triethyl orthoformate $(1.00 \mathrm{mmol})$ was refluxed in butan-1-ol $(10 \mathrm{~mL}) . o$-Phenylenediamine $(1.00 \mathrm{mmol})$ was added after approximately 1 hour, when the color of the reaction mixture changed to red. The resulting mixture was refluxed for 3 hours.

Reaction conditions B: A stirred mixture of compound 1a-d (1.00 mmol), appropriate aniline (1.00 mmol) and triethyl orthoformate $(1 \mathrm{~mL})$ was refluxed in butan-1-ol $(10 \mathrm{~mL})$ for 4 hours.

4.1.8.1. 5-[[(2-Aminophenyl)amino]methylene]-2-thioxodihydropyrimidine-4,6(1H,5H)-dione (7a). From thiobarbituric acid (1b) by reaction conditions A; Yield 81\%; dark yellow solid; mp 247-249 ${ }^{\circ} \mathrm{C}$; IR $v_{\max }\left(\mathrm{cm}^{-}\right.$ 1) $3429,3342,3098,2998,2894,1688,1616,1587,1538,1471,1330,1309,1162,1008,868,776$; ${ }^{1} \mathrm{H}$ NMR

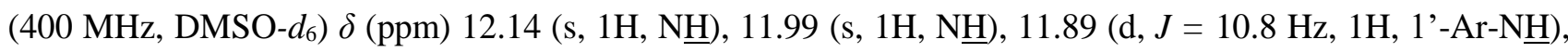
$8.43(\mathrm{~d}, J=10.8 \mathrm{~Hz}, 1 \mathrm{H}, 5-\mathrm{CC} \underline{\mathrm{H}}), 7.35$ (d, $\left.J=7.8 \mathrm{~Hz}, 1 \mathrm{H}, 6^{\prime}-\mathrm{ArC} \underline{\mathrm{H}}\right), 7.05$ (t, $\left.J=7.6 \mathrm{~Hz}, 1 \mathrm{H}, 4^{\prime}-\mathrm{ArC} \underline{\mathrm{H}}\right), 6.87$ $\left(\mathrm{d}, J=7.7 \mathrm{~Hz}, 1 \mathrm{H}, 3^{\prime}-\mathrm{ArC} \underline{\mathrm{H}}\right), 6.73\left(\mathrm{t}, J=7.5 \mathrm{~Hz}, 1 \mathrm{H}, 5^{\prime}\right.$-ArC $\left.\underline{\mathrm{H}}\right), 5.20\left(\mathrm{~s}, 2 \mathrm{H}, 1^{\prime}-\mathrm{Ar}-\mathrm{N}_{2}\right) ;{ }^{13} \mathrm{C} \mathrm{NMR}(101$

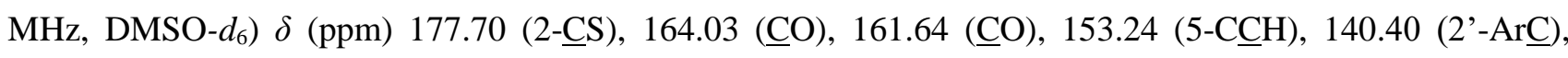

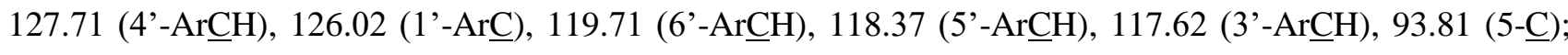
ESI-HRMS Calcd for $[\mathrm{M}+\mathrm{Na}]^{+} \mathrm{C}_{11} \mathrm{H}_{10} \mathrm{~N}_{4} \mathrm{O}_{2} \mathrm{NaS} 285.0417$, found 285.0407. 


\subsubsection{5-[[(2-Chloro-5-nitrophenyl)amino]methyleno]-2-thioxodihydropyrimidine-4,6(1H,5H)-dione}

(7b). From thiobarbituric acid (1b) and 2-chloro-5-nitroaniline by reaction conditions B; Yield 97\%; dark white solid; $\mathrm{mp} 348-349{ }^{\circ} \mathrm{C}$; IR $v_{\max }\left(\mathrm{cm}^{-1}\right) 3074,2891,1686,1620,1592,1576,1517,1458,1345,1317$, 1301, 1161, 1053, 1003, 848, 795, 740; ${ }^{1} \mathrm{H}$ NMR (400 MHz, DMSO- $\left.d_{6}\right) \delta(\mathrm{ppm}) 12.57(\mathrm{~d}, J=13.1 \mathrm{~Hz}, 1 \mathrm{H}$,

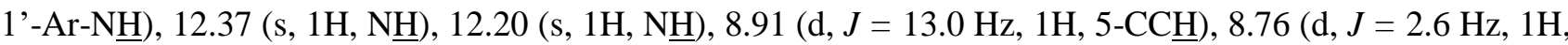
6'-Cㅌ) $, 8.06\left(\mathrm{dd}, J=8.8\right.$ and $\left.2.6 \mathrm{~Hz}, 1 \mathrm{H}, 4^{\prime}-\mathrm{C} \underline{\mathrm{H}}\right), 7.89\left(\mathrm{~d}, J=8.8 \mathrm{~Hz}, 1 \mathrm{H}, 3^{\prime}-\mathrm{C} \underline{\mathrm{H}}\right) ;{ }^{13} \mathrm{C}$ NMR $(101 \mathrm{MHz}$

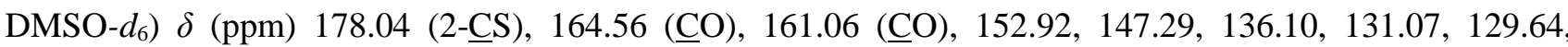
120.96, 113.70, 96.17 (5-C). ESI-HRMS Calcd for $[\mathrm{M}+\mathrm{H}]^{+} \mathrm{C}_{11} \mathrm{H}_{8} \mathrm{ClN}_{4} \mathrm{O}_{4} \mathrm{~S}$ 326.9949, found 326.9947.

\subsubsection{5-[[(2-Chloro-5-nitrophenyl)amino]methyleno]-1,3-dimethylpyrimidine-2,4,6(1H,3H,5H)-trione}

(7c). From 1,3-dimethylbarbituric acid (1c) and 2-chloro-5-nitroaniline by reaction conditions B; Yield 92\%; white solid; mp 257-259 ${ }^{\circ} \mathrm{C}$; IR $v_{\max }\left(\mathrm{cm}^{-1}\right) 3068,2956,1731,1631,1599,1573,1528,1498,1466,1419$, $1344,1293,1204,1086,1053,1000,882,825,740 ;{ }^{1} \mathrm{H}$ NMR (400 MHz, DMSO-d $\left.)_{6}\right) \delta(\mathrm{ppm}) 12.52\left(\mathrm{~s}, 1 \mathrm{H}, 1^{\prime}-\right.$

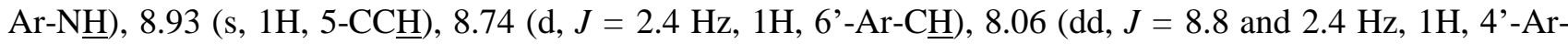
$\mathrm{CH}), 7.89\left(\mathrm{~d}, J=8.8 \mathrm{~Hz}, 1 \mathrm{H}, 3^{\prime}-\mathrm{Ar}-\mathrm{C} \underline{\mathrm{H}}\right), 3.23\left(\mathrm{~s}, 6 \mathrm{H}, 2 \times \mathrm{NCH}_{3}\right) ;{ }^{13} \mathrm{C}$ NMR $\left(101 \mathrm{MHz}, \mathrm{DMSO}-d_{6}\right) \delta(\mathrm{ppm})$ 164.67 (므), 161.38 (므), 152.26, 151.14 (2-므), 147.31, 136.26, 131.02, 129.46, 120.59, 113.26, 95.00 (5C), $27.66\left(\mathrm{NCH}_{3}\right), 27.15\left(\mathrm{NCH}_{3}\right)$; ESI-HRMS Calcd for $[\mathrm{M}+\mathrm{H}]^{+} \mathrm{C}_{13} \mathrm{H}_{12} \mathrm{ClN}_{4} \mathrm{O}_{5} 339.0490$, found 339.0485.

\subsubsection{5-[[(2-Chloro-4-nitrophenyl)amino]methyleno]-2-thioxodihydropyrimidine-4,6(1H,5H)-dione}

(7d). From thiobarbituric acid (1b) and 2-chloro-4-nitroaniline by reaction conditions B; Yield 91\%; yellow solid; mp $365{ }^{\circ} \mathrm{C}$ dec.; IR $v_{\max }\left(\mathrm{cm}^{-1}\right) 3332,3053,2880,1698,1650,1575,1506,1457,1347,1302,1288$ $1267,1139,815,744,731 ;{ }^{1} \mathrm{H}$ NMR (400 MHz, DMSO- $\left.d_{6}\right) \delta(\mathrm{ppm}) 12.63$ (d, $J=12.9 \mathrm{~Hz}, 1 \mathrm{H}, 1$ '-Ar-N $\left.\underline{\mathrm{H}}\right)$,

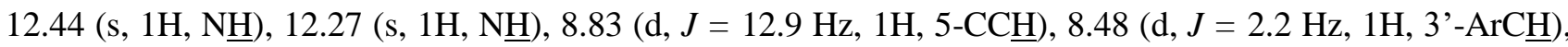
$8.25\left(\mathrm{dd}, J=9.2\right.$ and $\left.1.9 \mathrm{~Hz}, 1 \mathrm{H}, 5^{\prime}-\mathrm{ArCH}\right), 8.19\left(\mathrm{~d}, J=9.2 \mathrm{~Hz}, 1 \mathrm{H}, 6^{\prime}-\mathrm{ArC} \underline{\mathrm{H}}\right) ;{ }^{13} \mathrm{C}$ NMR $(101 \mathrm{MHz}, \mathrm{DMSO}-$

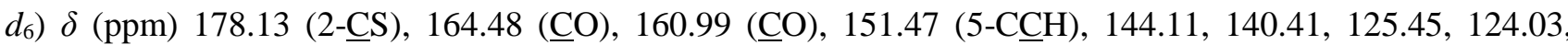
123.08, 117.96, 97.31 (5-C)); ESI-HRMS Calcd for $[\mathrm{M}+\mathrm{H}]^{+} \mathrm{C}_{11} \mathrm{H}_{8} \mathrm{ClN}_{4} \mathrm{O}_{4} \mathrm{~S}$ 326.9949, found 326.9947.

4.1.8.5. 5-[[(2-Chlorophenyl)amino]methyleno]-2-thioxodihydropyrimidine-4,6(1H,5H)-dione (7e). From thiobarbituric acid (1b) and 2-chloroaniline by reaction conditions B; Yield 93\%; pale yellow solid; mp 357$358{ }^{\circ} \mathrm{C}$; IR v váx $\left(\mathrm{cm}^{-1}\right) 3106,3008,2894,2562,1680,1621,1599,1588,1571,1536,1496,1442,1316,1285$, 
1157, 1053, 1000, 854, 802, 767; ${ }^{1} \mathrm{H}$ NMR (400 MHz, DMSO- $\left.d_{6}\right) \delta(\mathrm{ppm}) 12.53$ (d, $J=13.4 \mathrm{~Hz}, 1 \mathrm{H}, 1$ '-Ar$\mathrm{N} \underline{\mathrm{H}}), 12.31(\mathrm{~s}, 1 \mathrm{H}, \mathrm{N} \underline{\mathrm{H}}), 12.14(\mathrm{~s}, 1 \mathrm{H}, \mathrm{N} \underline{\mathrm{H}}), 8.74(\mathrm{~d}, J=13.4 \mathrm{~Hz}, 1 \mathrm{H}, 5-\mathrm{CC} \underline{\mathrm{H}}), 7.93(\mathrm{~d}, J=8.1 \mathrm{~Hz}, 1 \mathrm{H}$, $\operatorname{ArC} \underline{H}), 7.62(\mathrm{dd}, J=8.0$ and $1.1 \mathrm{~Hz}, 1 \mathrm{H}, \operatorname{ArC} \underline{\mathrm{H}}), 7.45(\mathrm{t}, J=7.7 \mathrm{~Hz}, 1 \mathrm{H}, \operatorname{ArC} \underline{\mathrm{H}}), 7.29(\mathrm{td}, J=7.7$ and 1.1

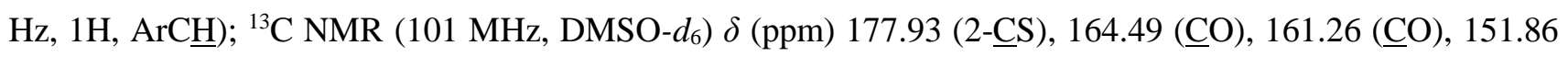

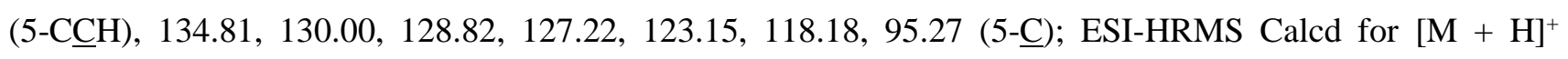
$\mathrm{C}_{11} \mathrm{H}_{9} \mathrm{ClN}_{3} \mathrm{O}_{2} \mathrm{~S} 282.0098$, found 282.0095.

4.1.8.6. 5-[[(2-Nitrophenyl)amino]methylene]-2-thioxodihydropyrimidine-4,6(1H,5H)-dione (7f). From thiobarbituric acid (1b) and 2-nitroaniline by reaction conditions B; Yield 98\%; yellow solid; $\mathrm{mp} 330{ }^{\circ} \mathrm{C}$ dec.; IR $v_{\max }\left(\mathrm{cm}^{-1}\right) 3121,3062,2899,1684,1633,1587,1567,1532,1511,1436,1337,1299,1261,1151,991$, 856, 790, 740; ${ }^{1} \mathrm{H}$ NMR (400 MHz, DMSO- $\left.d_{6}\right) \delta(\mathrm{ppm}) 13.33$ (d, $J=13.3 \mathrm{~Hz}, 1 \mathrm{H}, 1$ ' -Ar-N $\left.\underline{\mathrm{H}}\right), 12.32$ (s, $1 \mathrm{H}$, $\mathrm{N} \underline{\mathrm{H}}), 12.18(\mathrm{~s}, 1 \mathrm{H}, \mathrm{N} \underline{\mathrm{H}}), 8.72(\mathrm{~d}, J=13.3 \mathrm{~Hz}, 1 \mathrm{H}, 5-\mathrm{CC} \underline{\mathrm{H}}), 8.26$ (dd, $J=8.4$ and $1.0 \mathrm{~Hz}, 1 \mathrm{H}, \operatorname{ArC} \underline{\mathrm{H}}), 8.09$ (d, $J=8.2 \mathrm{~Hz}, 1 \mathrm{H}, \mathrm{ArC} \underline{\mathrm{H}}), 7.86(\mathrm{td}, J=7.9$ and $1.1 \mathrm{~Hz}, 1 \mathrm{H}, \mathrm{ArC} \underline{\mathrm{H}}), 7.47(\mathrm{td}, J=7.8$ and $1.0 \mathrm{~Hz}, 1 \mathrm{H}, \mathrm{ArC} \underline{\mathrm{H}}) ;{ }^{13} \mathrm{C}$

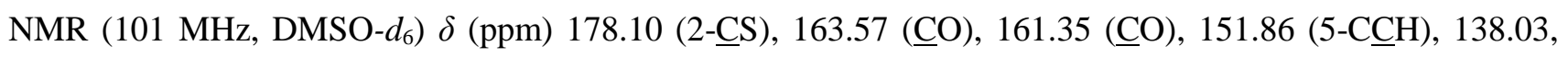
136.23, 133.94, 126.20, 125.98, 119.60, 96.75 (5-C); ESI-HRMS Calcd for $[\mathrm{M}+\mathrm{H}]^{+} \mathrm{C}_{11} \mathrm{H}_{9} \mathrm{~N}_{4} \mathrm{O}_{4} \mathrm{~S} 293.0339$, found 293.0336.

\subsubsection{2-[[(4,6-Dioxo-1,3-diphenyl-2-thioxotetrahydropyrimidin-5(2H)-ylidene)methyl]amino]benzoic}

acid (7g). From 1,3-diphenylthiobarbituric acid (1a) and 2-aminobenzoic acid by reaction conditions B; Yield 83\%; yellow solid; mp 322-324 ${ }^{\circ} \mathrm{C}$; IR $v_{\text {máx }}\left(\mathrm{cm}^{-1}\right) 3400$ to 2700 (broad), 3061, 1689, 1660, 1644, 1607, 1569, 1439, 1324, 1290, 1259, 1208, 1147, 1070, 753, 723, 691; ${ }^{1} \mathrm{H}$ NMR (400 MHz, DMSO- $\left.d_{6}\right) \delta(\mathrm{ppm}) 13.82$ (s,

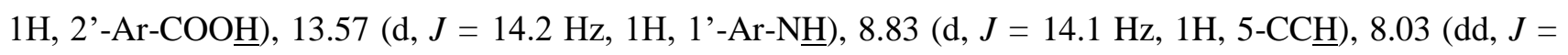
7.9 and $1.8 \mathrm{~Hz}, 1 \mathrm{H}, \operatorname{ArC} \underline{\mathrm{H}}), 7.88(\mathrm{~d}, J=8.4 \mathrm{~Hz}, 1 \mathrm{H}, \mathrm{ArC} \underline{\mathrm{H}}), 7.73$ (td, $J=7.6$ and $1.2 \mathrm{~Hz}, 1 \mathrm{H}, \mathrm{ArC} \underline{\mathrm{H}}), 7.52-$

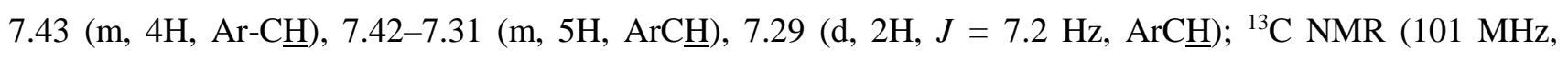

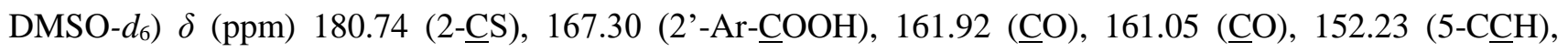
$140.30,139.66,139.33,134.58,131.68,129.27,129.09$, 128.90, 128.84, 128.00, 127.88, 125.81, 119.30, 117.50, 96.12 (5-C); ESI-HRMS Calcd for $[\mathrm{M}+\mathrm{Na}]^{+} \mathrm{C}_{24} \mathrm{H}_{17} \mathrm{~N}_{3} \mathrm{O}_{4} \mathrm{NaS} 466.0832$, found 466.0823.

4.1.8.8. 2-[[(4,6-Dioxo-2-thioxotetrahydropyrimidin-5(2H)-ylidene)methyl]amino]benzoic acid

(7h).

From thiobarbituric acid (1b) and 2-aminobenzoic acid by reaction conditions B; Yield 97\%; dark white solid; 
mp $365{ }^{\circ} \mathrm{C}$ dec. (lit [27] 340-344 ${ }^{\circ} \mathrm{C}$ ); IR $v_{\max }\left(\mathrm{cm}^{-1}\right) 3142$ to 2511 (broad), 3142, 3041, 2966, 2892, 1676, $1602,1581,1527,1457,1437,1348,1321,1288,1251,1158,1008,858,757$; ${ }^{1} \mathrm{H}$ NMR (400 MHz, DMSO$\left.d_{6}\right) \delta(\mathrm{ppm}) 13.86$ (s, 1H, 2'-Ar-COO프), 13.53 (d, $\left.J=14.0 \mathrm{~Hz}, 1 \mathrm{H}, 1^{\prime}-\operatorname{Ar}-\mathrm{N} \underline{\mathrm{H}}\right), 12.14(\mathrm{~s}, 1 \mathrm{H}, \mathrm{N} \underline{\mathrm{H}}), 12.05$ (s, $1 \mathrm{H}, \mathrm{N} \underline{\mathrm{H}}), 8.67(\mathrm{~d}, J=14.0 \mathrm{~Hz}, 1 \mathrm{H}, 5-\mathrm{CC} \underline{\mathrm{H}}), 8.03(\mathrm{~d}, J=7.7 \mathrm{~Hz}, 1 \mathrm{H}, \operatorname{ArC} \underline{\mathrm{H}}), 7.86(\mathrm{~d}, J=8.4 \mathrm{~Hz}, 1 \mathrm{H}, \operatorname{ArC} \underline{\mathrm{H}})$, $7.70(\mathrm{t}, J=7.5 \mathrm{~Hz}, 1 \mathrm{H}, \mathrm{ArC} \underline{\mathrm{H}}), 7.35(\mathrm{t}, J=7.6 \mathrm{~Hz}, 1 \mathrm{H}, \mathrm{ArC} \underline{\mathrm{H}}) ;{ }^{13} \mathrm{C}$ NMR $\left(101 \mathrm{MHz}, \mathrm{DMSO}-d_{6}\right) \delta(\mathrm{ppm})$

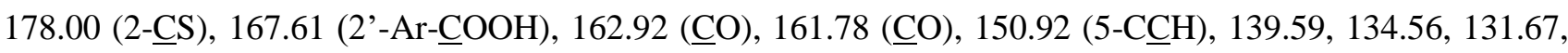
125.50, 118.91, 117.30, $95.48(5-\underline{\mathrm{C}})$.

4.1.8.9. 2-[[(1,3-Dimethyl-2,4,6-trioxotetrahydropyrimidin-5(2H)-ylidene)methyl]amino]benzoic acid (7i). From 1,3-dimethylbarbituric acid (1c) and 2-aminobenzoic acid by reaction conditions B; Yield 77\%; pale yellow needle crystals; mp 314-315 ${ }^{\circ} \mathrm{C}$ (lit [66] $210{ }^{\circ} \mathrm{C}$ ); IR $v_{\max }\left(\mathrm{cm}^{-1}\right) 3300$ to 2600 (broad), 3083, 1715, $1644,1602,1577,1450,1355,1315,1197,1142,1072,1013,869,789,752 ;{ }^{1} \mathrm{H}$ NMR (400 MHz, DMSO-d $)$ $\delta(\mathrm{ppm}) 13.60$ (s, 1H, 2'-Ar-COOH$), 13.46$ (d, $J=14.1 \mathrm{~Hz}, 1 \mathrm{H}, 1^{\prime}$ '-Ar-N $\left.\underline{\mathrm{H}}\right), 8.67$ (d, $J=13.9 \mathrm{~Hz}, 1 \mathrm{H}, 5-$ $\mathrm{CC} \underline{\mathrm{H}}), 8.01(\mathrm{~d}, J=7.7 \mathrm{~Hz}, 2 \mathrm{H}, \mathrm{ArC} \underline{\mathrm{H}}), 7.79(\mathrm{~d}, J=8.4 \mathrm{~Hz}, 1 \mathrm{H}, \mathrm{ArC} \underline{\mathrm{H}}), 7.69$ (t, $J=7.7 \mathrm{~Hz}, 1 \mathrm{H}, \operatorname{ArC} \underline{\mathrm{H}}), 7.32$ $(\mathrm{t}, J=7.5 \mathrm{~Hz}, 1 \mathrm{H}, \mathrm{ArC} \underline{\mathrm{H}}), 3.18\left(\mathrm{~d}, J=3.1 \mathrm{~Hz}, 6 \mathrm{H}, 2 \times \mathrm{NC}_{3}\right) ;{ }^{13} \mathrm{C} \mathrm{NMR}\left(101 \mathrm{MHz}, \mathrm{DMSO}-d_{6}\right) \delta(\mathrm{ppm})$

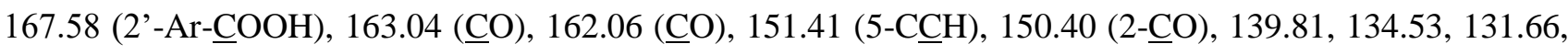
125.09, 118.69, 116.83, 94.19 (5-뜨), $27.64\left(\mathrm{~N}^{\mathrm{CH}}{ }_{3}\right), 27.03\left(\mathrm{NCH}_{3}\right)$.

4.1.8.10. 2-[[(2,4,6-Trioxotetrahydropyrimidin-5(2H)-ylidene)methyl $]$ amino]benzoic acid (7j). From barbituric acid (1d) and 2-aminobenzoic acid by reaction conditions B; Yield 84\%; white solid; mp 365 ${ }^{\circ} \mathrm{C}$ dec. (lit [27] 310-314 ${ }^{\circ} \mathrm{C}$ ); IR $v_{\max }\left(\mathrm{cm}^{-1}\right) 3163$ to 2514 (broad), 3136, 3084, 2815, 1729, 1673, 1614, 1593, $1573,1503,1458,1439,1420,1350,1324,1290,1255,941,856,795,758 ;{ }^{1} \mathrm{H}$ NMR $\left(400 \mathrm{MHz}, \mathrm{DMSO}-d_{6}\right) \delta$

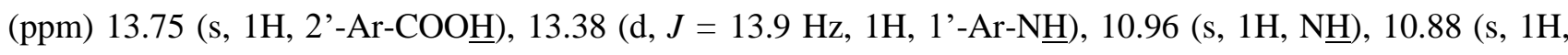
$\mathrm{N} \underline{\mathrm{H}}), 8.62(\mathrm{~d}, J=13.8 \mathrm{~Hz}, 1 \mathrm{H}, 5-\mathrm{CC} \underline{\mathrm{H}}), 8.02(\mathrm{~d}, J=7.6 \mathrm{~Hz}, 1 \mathrm{H}, \operatorname{ArC} \underline{\mathrm{H}}), 7.81(\mathrm{~d}, J=8.4 \mathrm{~Hz}, 1 \mathrm{H}, \operatorname{ArC} \underline{\mathrm{H}})$, $7.69(\mathrm{t}, J=7.9 \mathrm{~Hz}, 1 \mathrm{H}, \mathrm{ArC} \underline{\mathrm{H}}), 7.32(\mathrm{t}, J=7.6 \mathrm{~Hz}, 1 \mathrm{H}, \mathrm{ArC} \underline{\mathrm{H}}) ;{ }^{13} \mathrm{C}$ NMR $\left(101 \mathrm{MHz}, \mathrm{DMSO}-d_{6}\right) \delta(\mathrm{ppm})$

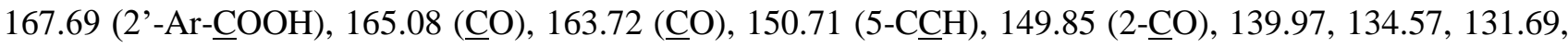
124.97, 118.57, 116.87, 94.26 (5-ㄷ).

4.1.9. 1-[(Pyrimidin-5-ylidene)methyl]ureas 8a-g. A stirred mixture of compound 1a-d (1.00 mmol), urea/thiourea $(1.00 \mathrm{mmol})$ and triethyl orthoformate $(1.50 \mathrm{mmol})$ was refluxed in butan-1-ol $(10 \mathrm{~mL})$ for 4 
hours. The formed product was filtered and washed with diethyl ether to give the following 1-(pyrimidin-5ylidene)ureas:

4.1.9.1. 1-[(4,6-Dioxo-2-thioxotetrahydropyrimidin-5(2H)-ylidene)methyl]urea (8a). From thiobarbituric acid (1b) and urea; Yield $77 \%$; reddish solid; mp 298-300 ${ }^{\circ} \mathrm{C}$; IR $v_{\max }\left(\mathrm{cm}^{-1}\right) 3406,3147,2889,1730,1693$, $1643,1529,1375,1259,1149,815,757 ;{ }^{1} \mathrm{H}$ NMR (400 MHz, DMSO-d $d_{6} \delta(\mathrm{ppm}) 12.19(\mathrm{~s}, 1 \mathrm{H}, \mathrm{N} \underline{\mathrm{H}}), 12.13$ $(1 \mathrm{H}, \mathrm{s}, \mathrm{N} \underline{\mathrm{H}}), 11.24(\mathrm{~d}, J=13.2 \mathrm{~Hz}, 1 \mathrm{H}, 5-\mathrm{CCHN} \underline{\mathrm{H}}), 8.54$ (d, $J=13.1 \mathrm{~Hz}, 1 \mathrm{H}, 5-\mathrm{CC} \underline{\mathrm{H}}), 7.88\left(\mathrm{~s}, 1 \mathrm{H}, \mathrm{N}_{2}\right)$,

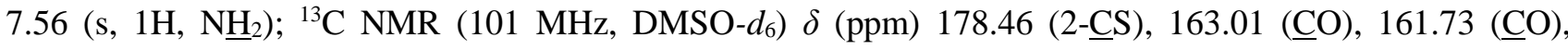

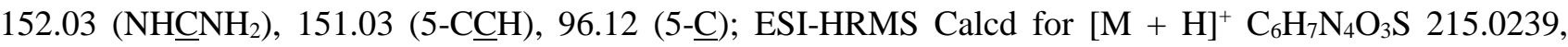
found 215.0237 .

4.1.9.2. 1-[(1,3-Dimethyl-2,4,6-trioxotetrahydropyrimidin-5(2H)-ylidene)methyl]urea $(8 \mathrm{~b})$. From $1,3-$ dimethylbarbituric acid (1c) and urea; Yield 52\%; yellow solid; mp 260-261 ${ }^{\circ} \mathrm{C}$; IR $v_{\max }\left(\mathrm{cm}^{-1}\right) 3371,3278$, $3197,1704,1666,1635,1560,1406,1371,1255,1085 ;{ }^{1} \mathrm{H}$ NMR $\left(400 \mathrm{MHz}, \mathrm{DMSO}-d_{6}\right) \delta(\mathrm{ppm}) 11.23(\mathrm{~d}, J=$ $13.1 \mathrm{~Hz}, 1 \mathrm{H}, 5-\mathrm{CCHN} \underline{\mathrm{H}}), 8.61(\mathrm{~d}, J=13.1 \mathrm{~Hz}, 1 \mathrm{H}, 5-\mathrm{CC} \underline{\mathrm{H}}), 7.82\left(\mathrm{~s}, 1 \mathrm{H}, \mathrm{N}_{2}\right), 7.47\left(\mathrm{~s}, 1 \mathrm{H}, \mathrm{N}_{2}\right), 3.17(\mathrm{~d}, J$ $\left.=3.7 \mathrm{~Hz}, 6 \mathrm{H}, 2 \times \mathrm{N}_{-} \underline{\mathrm{H}}_{3}\right) ;{ }^{13} \mathrm{C} \mathrm{NMR}\left(101 \mathrm{MHz}, \mathrm{DMSO}-d_{6}\right) \delta(\mathrm{ppm}) 163.24(\underline{\mathrm{CO}}), 161.95$ (므), 152.17

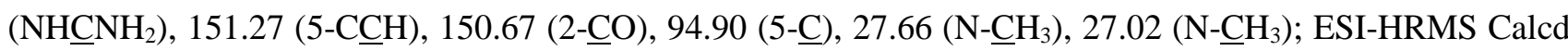
for $[\mathrm{M}+\mathrm{H}]{ }^{+} \mathrm{C}_{8} \mathrm{H}_{11} \mathrm{~N}_{4} \mathrm{O}_{4} 227.0780$, found 227.0780.

4.1.9.3. 1-[(2,4,6-Trioxotetrahydropyrimidin-5(2H)-ylidene)methyl]urea (8c). From barbituric acid (1d) and urea; Yield 71\%; light-brown solid; mp 248-250 ${ }^{\circ} \mathrm{C}$; IR $v_{\max }\left(\mathrm{cm}^{-1}\right) 3411,3172,1733,1703,1629,1569$, 1384, 1305, 1272, 792; ${ }^{1} \mathrm{H}$ NMR (400 MHz, DMSO- $\left.d_{6}\right) \delta(\mathrm{ppm}) 11.10(\mathrm{~d}, J=13.1 \mathrm{~Hz}, 1 \mathrm{H}, 5-\mathrm{CCHN} \underline{\mathrm{H}}), 11.06$ $(\mathrm{s}, 1 \mathrm{H}, \mathrm{N} \underline{\mathrm{H}}), 10.97(\mathrm{~s}, 1 \mathrm{H}, \mathrm{N} \underline{\mathrm{H}}), 8.51(\mathrm{~d}, J=13.1 \mathrm{~Hz}, 1 \mathrm{H}, 5-\mathrm{CC} \underline{\mathrm{H}}), 7.83\left(\mathrm{~s}, 1 \mathrm{H}, \mathrm{N}_{2}\right), 7.46\left(\mathrm{~s}, 1 \mathrm{H}, \underline{\mathrm{N}}_{2}\right) ;{ }^{13} \mathrm{C}$

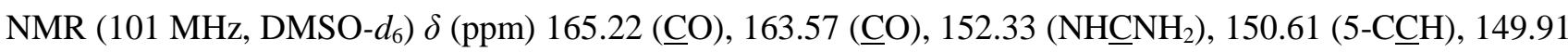
(2-으), 95.08 (5-ㄷ) ; ESI-HRMS Calcd for $\left(\mathrm{M}^{+}+\mathrm{Na}\right) \mathrm{C}_{6} \mathrm{H}_{6} \mathrm{~N}_{4} \mathrm{O}_{4} \mathrm{Na} 221.0281$, found 221.0282.

From 1,3-diphenylthiobarbituric acid (1a) and thiourea; Yield 85\%; orange solid; mp 259-261 ${ }^{\circ} \mathrm{C}$ (lit 263-264 $\left.{ }^{\circ} \mathrm{C}[67]\right) ; \mathrm{IR} v_{\max }\left(\mathrm{cm}^{-1}\right) 3442,3263,3172,3051,1685,1654,1591,1487,1402,1321,1217,1190,1153,823$, 688; ${ }^{1} \mathrm{H}$ NMR (400 MHz, DMSO- $\left.d_{6}\right) \delta(\mathrm{ppm}) 12.13$ (d, $\left.J=11.7 \mathrm{~Hz}, 1 \mathrm{H}, 5-\mathrm{CCHN} \underline{\mathrm{H}}\right), 9.72\left(\mathrm{~s}, 1 \mathrm{H}, \mathrm{N}_{2}\right), 9.44$ 
(s, $\left.1 \mathrm{H}, \mathrm{N}_{2}\right), 9.28$ (d, $\left.J=11.7 \mathrm{~Hz}, 1 \mathrm{H}, 5-\mathrm{CC} \underline{\mathrm{H}}\right), 7.49-7.27$ (m, 10H, ArC$) ;{ }^{13} \mathrm{C}$ NMR $\left(101 \mathrm{MHz}, \mathrm{DMSO}-d_{6}\right)$

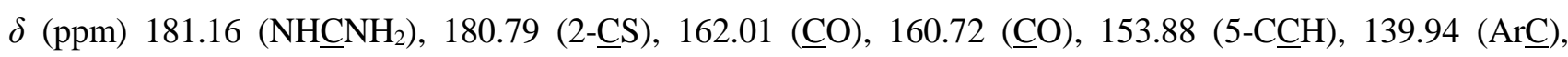
$139.29(\operatorname{Ar} \underline{\mathrm{C}}), 128.96(2 \times \operatorname{Ar} \underline{\mathrm{CH}}), 128.91(2 \times \operatorname{Ar} \underline{\mathrm{CH}}), 128.80(2 \times \operatorname{Ar} \underline{\mathrm{CH}}), 128.75(2 \times \operatorname{Ar} \underline{\mathrm{CH}}), 128.00$ (ArCH), $127.94(\mathrm{Ar} \underline{\mathrm{CH}}), 98.49$ (5-C)$)$, ESI-HRMS Calcd for $[\mathrm{M}+\mathrm{H}]^{+} \mathrm{C}_{18} \mathrm{H}_{15} \mathrm{~N}_{4} \mathrm{O}_{2} \mathrm{~S}_{2}$ 383.0636, found 383.0635 .

4.1.9.5. 1-[(4,6-Dioxo-2-thioxotetrahydropyrimidin-5(2H)-ylidene)methyl]thiourea

(8e). From thiobarbituric acid (1b) and thiourea; Yield 74\%; red solid; mp $252{ }^{\circ} \mathrm{C}$ dec.; IR $v_{\max }\left(\mathrm{cm}^{-1}\right) 3284,3136,1695$, $1664,1574,1506,1413,1259,1143,1012,997,804 ;{ }^{1} \mathrm{H}$ NMR (400 MHz, DMSO-d $) \delta(\mathrm{ppm}) 12.32(\mathrm{~s}, 1 \mathrm{H}$, $\mathrm{NH}), 12.23(\mathrm{~s}, 1 \mathrm{H}, \mathrm{NH}), 11,94(\mathrm{~d}, J=13.1 \mathrm{~Hz}, 1 \mathrm{H}, 5-\mathrm{CCHNH}), 9.70\left(\mathrm{~s}, 1 \mathrm{H}, \mathrm{N}_{2}\right), 9.55\left(\mathrm{~s}, 1 \mathrm{H}, \mathrm{N}_{2}\right), 9.11(\mathrm{~d}$, $J=13.1 \mathrm{~Hz}, 1 \mathrm{H}, 5-\mathrm{CC} \underline{\mathrm{H}}) ;{ }^{13} \mathrm{C}$ NMR $\left(101 \mathrm{MHz}, \mathrm{DMSO}-d_{6}\right) \delta(\mathrm{ppm}) 181.31\left(\mathrm{NHCNH}_{2}\right), 178.48$ (2-ㄷS),

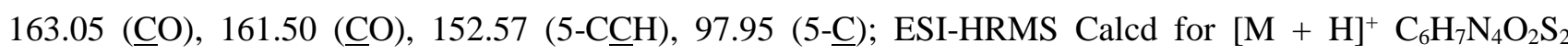
231.0010, found 231.0013.

4.1.9.6. 1-[(1,3-Dimethyl-2,4,6-trioxotetrahydropyrimidin-5(2H)-ylidene)methyl]thiourea (8f). From 1,3dimethylbarbituric acid (1c) and thiourea; Yield 89\%; yellow solid; mp 267-270 ${ }^{\circ} \mathrm{C}$; IR $v_{\max }\left(\mathrm{cm}^{-1}\right) 3290$, $3145,1716,1635,1589,1469,1429,1338,1230,1186,1086,798,754 ;{ }^{1} \mathrm{H}$ NMR (400 MHz, DMSO- $\left.d_{6}\right) \delta$

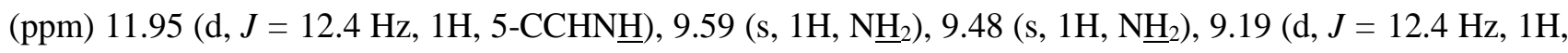
5-CC프), $3.19\left(\mathrm{~d}, J=3.3 \mathrm{~Hz}, 6 \mathrm{H}, 2 \times \mathrm{N}-\underline{\mathrm{H}}_{3}\right) ;{ }^{13} \mathrm{C} \mathrm{NMR}\left(101 \mathrm{MHz}, \mathrm{DMSO}-d_{6}\right) \delta(\mathrm{ppm}) 181.46\left(\mathrm{NHCNH}_{2}\right)$,

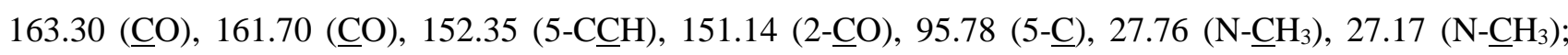
ESI-HRMS Calcd for $[\mathrm{M}+\mathrm{H}]^{+} \mathrm{C}_{8} \mathrm{H}_{11} \mathrm{~N}_{4} \mathrm{O}_{3} \mathrm{~S} 243.0552$, found 243.0551.

4.1.9.7. 1-[(2,4,6-Trioxotetrahydropyrimidin-5(2H)-ylidene)methyl]thiourea (8g). From barbituric acid (1d) and thiourea; Yield: 86\%; light-brown solid; mp $375{ }^{\circ} \mathrm{C}$ dec.; IR $v_{\max }\left(\mathrm{cm}^{-1}\right)$ 3280, 3217, 3145, 3045, 2808, 1733, 1701, 1645, 1571, 1438, 1407, 1247, 1024, 783; ${ }^{1} \mathrm{H}$ NMR (400 MHz, DMSO-d $) \delta(\mathrm{ppm}) 11.84$ (d, $J=12.3 \mathrm{~Hz}, 1 \mathrm{H}, 5-\mathrm{CCHN} \underline{\mathrm{H}}), 11.15(\mathrm{~s}, 1 \mathrm{H}, \mathrm{N} \underline{\mathrm{H}}), 11.03(\mathrm{~s}, 1 \mathrm{H}, \mathrm{N} \underline{\mathrm{H}}), 9.53$ (s, 1H, $\left.\underline{\mathrm{H}}_{2}\right), 9.45$ (s, 1H, $\left.\underline{\mathrm{H}}_{2}\right)$, $9.08(\mathrm{~d}, J=12.3 \mathrm{~Hz}, 1 \mathrm{H}, 5-\mathrm{CC} \underline{\mathrm{H}}) ;{ }^{13} \mathrm{C} \mathrm{NMR}\left(101 \mathrm{MHz}, \mathrm{DMSO}-d_{6}\right) \delta(\mathrm{ppm}) 181.52\left(\mathrm{NHCNH}_{2}\right), 165.17(\underline{\mathrm{CO}})$,

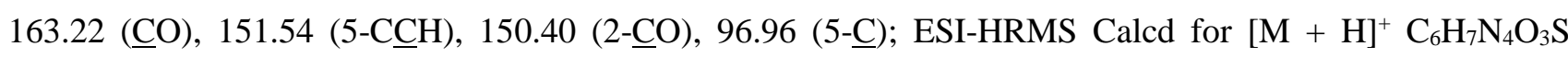
215.0239, found 215.0238 . 


\subsection{In vitro activity}

\subsubsection{Xanthine oxidase inhibitory activity}

\subsubsection{Preparation of sample solutions}

All assayed compounds were dissolved in DMSO in a concentration of $10 \mathrm{mM}$ for the initial screening and $50 \mathrm{mM}$ for the concentration-response studies. A $10 \mathrm{mM}$ xanthine stock solution was prepared in a $25 \mathrm{mM}$ aqueous $\mathrm{NaOH}$ solution. All stock solutions were stored at $4{ }^{\circ} \mathrm{C}$ and the diluted solutions were prepared in 50 $\mathrm{mM}$ dihydrogen phosphate buffer ( $\mathrm{pH}$ 7.4) before each experiment. The concentrations in each well were 30 $\mu \mathrm{M}$ for the initial screening as well as $0.1,1,7.5,15,30,50$ and $100 \mu \mathrm{M}$ for the concentration-response studies. The final concentration of DMSO in each well was $1 \%$, and no significant interference with the enzyme activity was observed (data not shown).

\subsubsection{Experimental procedure}

The xanthine oxidase (XO) activity was spectrophotometrically determined by quantifying the uric acid formation from xanthine adapting the methods of Zhao et al. [41] and Gupta et al. [68]. For each essay, $50 \mu \mathrm{L}$ of test solution and $50 \mu \mathrm{L}$ of a $\mathrm{XO}$ bovine serum suspension $(0.1 \mathrm{U} / \mathrm{mL})$ were added to each well of a 96-well plate followed by a pre-incubation at $37{ }^{\circ} \mathrm{C}$ for 5 minutes. The enzymatic reaction started after the addition of $150 \mu \mathrm{L}$ of xanthine $(0.42 \mathrm{mM})$ and further incubation at $37{ }^{\circ} \mathrm{C}$ during $10 \mathrm{~min}$. The absorbances were measured at $295 \mathrm{~nm}$ and at every minute, with 20 seconds of a constant and automatic slow stirring before each reading. Dihydrogen phosphate buffer $(50 \mathrm{mM}, \mathrm{pH}$ 7.4) was used as negative control and allopurinol as a positive control. In order to discount the absorbance of each compound at this wavelength, a blank sample containing $50 \mu \mathrm{L}$ of test solution and $200 \mu \mathrm{L}$ of buffer was performed. Three independent experiments, each one in triplicate, were performed. The percentage of enzyme inhibition for each compound was calculated according to the following formula:

$\%$ of inhibition $=\left[1-\left(\mathrm{Abs}_{\text {sample }}-\mathrm{Abs}_{\text {blank of sample }}\right) / \mathrm{Abs}_{\text {negative control }}\right] \times 100$

The direct breakdown of uric acid by the synthetized BADs and TBADs $\mathbf{2 - 8}$ was spectrophotometrically studied in experimental conditions similar to the established in enzymatic inhibition assays. For each assay, 50 
$\mu \mathrm{L}$ of test solution $(60 \mu \mathrm{M})$ and $50 \mu \mathrm{L}$ of uric acid $(200 \mu \mathrm{M})$ were added to each well of a 96-well plate. The absorbances were measured at $295 \mathrm{~nm}$ after further incubation at $37^{\circ} \mathrm{C}$ during $10 \mathrm{~min}$. In order to discount the absorbance of each compound at this wavelength, a blank sample containing $50 \mu \mathrm{L}$ of test solution and $50 \mu \mathrm{L}$ of buffer was performed. Three independent experiments, each one in triplicate, were performed. No significant interference with uric acid levels was observed for any compound under study.

\subsubsection{Radical scavenging activity}

\subsubsection{Preparation of sample solutions}

All assayed compounds were dissolved in DMSO in a $10 \mathrm{mM}$ concentration and stored at $4{ }^{\circ} \mathrm{C}$. The diluted solutions were prepared in $99.5 \%$ ethanol before each experiment. The concentrations in each well were 30 $\mu \mathrm{M}$ for the initial screening as well as $1,7.5,15,30,50$ and $100 \mu \mathrm{M}$ for the concentration-response studies.

\subsubsection{Experimental procedure}

The radical scavenging activity was spectrophotometrically determined by the quantification of the DPPH reduction extension by the compounds under study, according to Zhao et al.[41] and Nicolaides et al. [42]. The reaction mixture contained $100 \mu \mathrm{L}$ of the test solution and $100 \mu \mathrm{L}$ of the DPPH solution $(0.2 \mathrm{mM})$. The capacity of each compound to reduce DPPH was followed by measuring the absorbance at $517 \mathrm{~nm}$ after 20 and 60 minutes. The solutions remained in the absence of light between measurements. Ethanol was used as the negative control and Trolox as the positive control. To discount the absorbance of each compound at 517 $\mathrm{nm}$, for each test compound a blank was performed where DPPH was replaced by ethanol. Three independent experiments were performed, each one in triplicate. The reduction capacity of DPPH was calculated according to the following formula:

$\%$ Reduction $=\left[1-\left(\mathrm{Abs}_{\text {sample }}-\mathrm{Abs}_{\text {sample blank }} / \mathrm{Abs}_{\text {negative control }}\right)\right] \times 100$

\subsubsection{Antibacterial activity}

4.2.3.1. Sample solutions, bacteria, stock and growth conditions 
All the tested compounds were dissolved in DMSO in a concentration of $10 \mathrm{mM}$, stored at $4{ }^{\circ} \mathrm{C}$, and diluted with culture medium before assays.

The following strains were used in the study: Bacillus cereus ATCC11778, Staphylococcus aureus ATCC 25923, Escherichia coli ATCC 25922, Klebsiella pneumoniae ATCC 13883, Pseudomonas aeruginosa ATCC 27853, Salmonella enterica subsp. enterica serovar Typhimurium ATCC 13311 and Acinetobacter baumannii LMG 1025. All bacterial cultures were stocked at $-80{ }^{\circ} \mathrm{C}$ in medium with $20 \%$ glycerol. The bacteria were sub-cultured on Müeller Hinton Agar and incubated overnight at $37^{\circ} \mathrm{C}$ prior to each antimicrobial assay.

\subsubsection{Determination of minimum inhibitory concentration (MIC)}

The antibacterial activity of the test compounds was studied by measurement of MIC by broth microdilution method according with CLSI guidelines (M7-A6). The compounds were two-fold serially diluted in a 96-well plate with Müeller Hinton Broth (MHB) to a volume of $50 \mu \mathrm{L}$, to give a final concentration range from 200 to $1.56 \mu \mathrm{M}$. The maximum DMSO concentration was $2 \%(\mathrm{v} / \mathrm{v})$. Bacterial suspensions were prepared from overnight culture using sterile saline solution, i.e. $\mathrm{NaCl} 0.85 \%$ (w/v), adjusted to $0.5 \mathrm{McFarland}$ and diluted with MHB. Then $50 \mu \mathrm{L}$ of suspension was added to each well to a final concentration of about $5 \times 10^{5}$ colony forming units $/ \mathrm{ml}$, and the plate was incubated at $37{ }^{\circ} \mathrm{C}$ for $24 \mathrm{~h}$. Sterility, solvent and growth controls were included in the assays, also tetracycline was used as reference. The MIC was defined as the lowest concentration at which no growth was visually observed. Each test was carried out at least three independent times and modal MIC values were selected.

\subsubsection{Cytotoxicity in human cell lines}

\subsubsection{Preparation of sample solutions}

All the tested compounds were dissolved in DMSO in a concentration of $10 \mathrm{mM}$ and stored at $4{ }^{\circ} \mathrm{C}$. From this solution, several solutions of the compounds in study were prepared by their adequate dilutions in the complete culture medium before each experiment. The maximum DMSO concentration in the studies was $1 \%$ $(\mathrm{v} / \mathrm{v})$, a concentration with no significant effect on cell proliferation (data not shown). 


\subsubsection{Cells cultures}

The cells used in this study were human breast cancer cells (MCF-7) and normal human dermal fibroblasts (NHDF) and were obtained from American Type Culture Collection (ATCC). These cells were maintained at $37^{\circ} \mathrm{C}$ in a humidified atmosphere containing $5 \% \mathrm{CO}_{2}$. MCF-7 cells were cultured in high-glucose Dulbecco's modified Eagle's medium (DMEM) supplemented with 10\% fetal bovine serum (FBS) and 1\% antibiotic/antimycotic (10,000 units/mL penicillin, $10 \mathrm{mg} / \mathrm{mL}$ streptomycin and $25 \mu \mathrm{g} / \mathrm{mL}$ amphotericin B). The RPMI medium supplemented with $10 \%$ fetal bovine serum (FBS), L-glutamine ( $2 \mathrm{mM})$, HEPES (10 $\mathrm{mM})$, sodium pyruvate $(1 \mathrm{mM})$ and $1 \%$ antibiotic/antimycotic was used to culture NHDF cells. The cells used in the experiments were used in passages 26 to 31 (MCF-7) and 6 to 11 (NHDF).

\subsubsection{MTT assay}

The cell proliferation was evaluated by quantifying the extent of the reduction of 3-(4,5-dimethylthiazol-2yl)-2,5-diphenyltetrazolium bromide (MTT) according to a previously described procedure [52]. Cells were seeded in 96 -well plates $\left(2 \times 10^{4}\right.$ cells $\left./ \mathrm{mL}\right)$ in the culture medium and after $48 \mathrm{~h}$ of adherence they were treated with the different compounds and concentrations under study for $72 \mathrm{~h}$. Untreated cells were used as negative control and 5-FU as positive control. At the end of incubation, the medium was removed and replaced with fresh culture medium and MTT solution $[5 \mathrm{mg} / \mathrm{mL}$ in phosphate buffer saline $(\mathrm{NaCl} 137 \mathrm{mM}, \mathrm{KCl} 2.7 \mathrm{mM}$, $\mathrm{Na}_{2} \mathrm{HPO}_{4} 10 \mathrm{mM}$ and $\mathrm{KH}_{2} \mathrm{PO}_{4} 1.8 \mathrm{mM}$ ), $\left.\mathrm{pH} 7.4\right]$ and further incubated at $37{ }^{\circ} \mathrm{C}$ during $4 \mathrm{~h}$. Then, the medium-containing MTT was removed and formazan crystals were dissolved with DMSO followed by absorbance readings at $570 \mathrm{~nm}$. The cytotoxicity was expressed as the relative cell proliferation in percentage in comparison with the negative control cells.

\subsubsection{Statistics}

The results are expressed as mean values \pm standard error of the mean (SEM) and are representative of least two independent experiments. The difference between groups was considered statistically significant at $\mathrm{p}<0.05$ (Student's $t$-test). The $\mathrm{IC}_{50}$ values were calculated by sigmoidal fitting analysis considering a $95 \%$ confidence interval. 


\subsection{In silico simulations}

The structures of tested compounds were manually drawn in ChemBioDraw 13.0 software and the SMILES notation was obtained for each molecule. To calculate the parameters of Lipinski's rule of five, pharmacokinetic (absorption, distribution, metabolism and excretion) and toxicity properties, the SMILES notation in PkCSM online software (available from http://bleoberis.bioc.cam.ac.uk/pkcsm/prediction, accessed at 04.04.17) was employed [54].

\section{Acknowledgments}

This work is supported by FEDER funds through the POCI - COMPETE 2020 - Operational Programme Competitiveness and Internationalization in Axis I - Strengthening research, technological development and innovation (Project POCI-01-0145-FEDER-007491) and National Funds by FCT - Foundation for Science and Technology (Project UID/Multi /00709/2013). The authors also acknowledge the contribution of Dr. Adriana Santos for the revision of written English.

\section{References}

[1] J.W. Dundee, P.D.A. McIlroy, The history of the barbiturates, Anaesthesia, 37 (1982) 726-734.

[2] F. López-Muñoz, R. Ucha-Udabe, C. Alamo, The history of barbiturates a century after their clinical introduction, Neuropsychiatric Disease and Treatment, 1 (2005) 329.

[3] T.L. Lemke, D.A. Williams, Sedative-Hypnotics, in: Foye's Principles of Medicinal Chemistry, Wolters Kluwer Health, 2012, pp. 485-507.

[4] J. Wang, M.W. Radomski, C. Medina, J.F. Gilmer, MMP inhibition by barbiturate homodimers, Bioorganic \& Medicinal Chemistry Letters, 23 (2013) 444-447.

[5] K.M. Khan, M. Khan, A. Karim, M. Taha, N. Ambreen, A. Gojayev, S. Perveen, M.I. Choudhary, Xanthine oxidase inhibition by 5 -aryledene $N, N^{\prime}$-dimethylbarbituric acid derivatives, Journal of the Chemical Society of Pakistan, 35 (2013) 495-498.

[6] R.M. Shaker, E.A. Ishak, Barbituric acid utility in multi-component reactions, Zeitschrift für Naturforschung, 66b (2011) 1189 - 1201. 
[7] G.M. Ziarani, F. Aleali, N. Lashgari, Recent applications of barbituric acid in multicomponent reactions, RSC Advances, 6 (2016) 50895-50922.

[8] K.T. Mahmudov, M.N. Kopylovich, A.M. Maharramov, M.M. Kurbanova, A.V. Gurbanov, A.J.L. Pombeiro, Barbituric acids as a useful tool for the construction of coordination and supramolecular compounds, Coordination Chemistry Reviews, 265 (2014) 1-37.

[9] N. Kobra, K. Zahra, Barbituric acids in organic transformations, an outlook to the reaction media, MiniReviews in Organic Chemistry, 14 (2017) 143-173.

[10] A. Barakat, M.S. Islam, A.M. Al-Majid, S.M. Soliman, Y.N. Mabkhot, Z.A. Al-Othman, H.A. Ghabbour, H.-K. Fun, Synthesis of novel 5-monoalkylbarbiturate derivatives: new access to 1,2-oxazepines, Tetrahedron Letters, 56 (2015) 6984-6987.

[11] M. Bararjanian, S. Balalaie, B. Movassagh, A.M. Amani, One-pot synthesis of pyrano[2,3d]pyrimidinone derivatives catalyzed by $L$-proline in aqueous media, Journal of the Iranian Chemical Society, 6 (2009) 436-442.

[12] M. Bayat, Y. Bayat, S.S. Asayesh, One-pot synthesis of $2 H$-pyrano[2,3- $d]$ pyrimidine derivatives, Monatshefte für Chemie - Chemical Monthly, 143 (2011) 479-483.

[13] V.D. Dyachenko, R.P. Tkachev, Functionally-substituted alkoxyethylenes in reactions with nucleophiles: Part 2. Synthesis of noncyclic structures, benzene derivatives, 5-, 7-membered, and macroheterocycles, Russian Journal of Organic Chemistry, 42 (2006) 149-171.

[14] R. Ghahremanzadeh, F. Fereshtehnejad, A. Bazgir, Chromeno[2,3- $d$ ]pyrimidine-triones synthesis by a three-component coupling reaction, Chemical and Pharmaceutical Bulletin, 58 (2010) 516-520.

[15] M.A. Ismail, S. Al-Shihry, R.K. Arafa, U. El-Ayaan, Synthesis, antimicrobial activity and molecular modeling study of substituted 5-aryl-pyrimido[5,4-c]quinoline-2,4-diones, Journal of Enzyme Inhibition and Medicinal Chemistry, 28 (2013) 530-538.

[16] R.N. Kumar, T. Suresh, P.S. Mohan, A convenient one-pot synthesis of benzopyrimido[1,8]naphthyridines by Knoevenagel condensation, Chemistry of Heterocyclic Compounds, 40 (2004) 1490-1492. 
[17] N.D. Moirangthem, W.S. Laitonjam, A new and facile synthetic approach to substituted 2thioxoquinazolin-4-ones by the annulation of a pyrimidine derivative, Beilstein Journal of Organic Chemistry, 6 (2010) 1056-1060.

[18] A. Pati, P. Majumdar, S. Garnayak, A.K. Behera, R.K. Behera, Regiospecific ring closure reactions of 1,3-diphenylthiobarbituric acid and dimedone: Formation of spiro vs fused heterocycles, Indian Journal of Chemistry - Section B Organic and Medicinal Chemistry, 53 (2013) 384-391.

[19] H.S. Thokchom, A.D. Nongmeikapam, W.S. Laitonjam, Synthesis of fused pyrazolo-, isoxazolo-, pyrimido-, and pyridopyrimidines, Canadian Journal of Chemistry, 83 (2005) 1056-1062.

[20] M. Adib, M. Sayahi, H. Ziyadi, L.-G. Zhu, H. Bijanzadeh, A novel, one-pot, efficient synthesis of 2aroyl-1,4-diaryl-7,9-dimethyl-7,9-diazaspiro[4.5]deca-1,3-diene-6,8,10-triones, Synthesis, 2008 (2008) 32893294.

[21] A.S. Girgis, H. Farag, N.S.M. Ismail, R.F. George, Synthesis, hypnotic properties and molecular modeling studies of 1,2,7,9-tetraaza-spiro[4.5]dec-2-ene-6,8,10-triones, European Journal of Medicinal Chemistry, 46 (2011) 4964-4969.

[22] Y. Hu, D.-Q. Shi, An efficient synthesis of new dispiropyrrolidine derivatives via three-component 1,3dipolar cycloaddition reaction, Journal of Heterocyclic Chemistry, 50 (2013) E121-E125.

[23] Z. Huang, Q. Zhao, G. Chen, H. Wang, W. Lin, L. Xu, H. Liu, J. Wang, D. Shi, Y. Wang, An efficient synthesis of novel dispirooxindole derivatives via one-pot three-component 1,3-dipolar cycloaddition reactions, Molecules, 17 (2012) 12704-12717.

[24] H.-W. Zhao, T. Tian, B. Li, Z. Yang, H.-L. Pang, W. Meng, X.-Q. Song, X.-Q. Chen, Diastereoselective synthesis of dispirobarbiturates through $\mathrm{Et}_{3} \mathrm{~N}$-catalyzed [3+2] cycloaddition of barbituratebased olefins with 3-isothiocyanato oxindoles, Journal of Organic Chemistry, 80 (2015) 10380-10385.

[25] K.M. Khan, M. Khan, A. Ahmad, A. Irshad, L.B.S. Kardono, F. Rahim, S.M. Haider, S. Ahmed, S. Parveen, Antibacterial and antifungal activities of 5-arylidene- $N, N$-dimethylbarbiturates derivatives, Journal of the Chemical Society of Pakistan, 36 (2014) 1153-1157.

[26] H.M. Aly, M.M. Kamal, Efficient one-pot preparation of novel fused chromeno[2,3- $d]$ pyrimidine and pyrano[2,3-d]pyrimidine derivatives, European Journal of Medicinal Chemistry, 47 (2012) 18-23. 
[27] A. Rauf, S. Shahzad, M. Bajda, M. Yar, F. Ahmed, N. Hussain, M.N. Akhtar, A. Khan, J. Jonczyk, Design and synthesis of new barbituric- and thiobarbituric acid derivatives as potent urease inhibitors: Structure activity relationship and molecular modeling studies, Bioorganic \& Medicinal Chemistry, 23 (2015) 6049-6058.

[28] D.M. Neumann, A. Cammarata, G. Backes, G.E. Palmer, B.S. Jursic, Synthesis and antifungal activity of substituted 2,4,6-pyrimidinetrione carbaldehyde hydrazones, Bioorganic \& Medicinal Chemistry, 22 (2014) 813-826.

[29] A. Pati, P. Majumdar, S. Garnayak, A.K. Behera, R.K. Behera, Regiospecific ring closude reactions of 1,3.diphenylthiobarbituric acid and dimedone: Formation of spiro vs fused heterocycles, Indian Journal of Chemistry - Section B Organic and Medicinal Chemistry, 53 (2014) 384-391.

[30] R. Kumar, Darpan, S. Sharma, R. Singh, Xanthine oxidase inhibitors: a patent survey, Expert Opinion on Therapeutic Patents, 21 (2011) 1071-1108.

[31] A. Šmelcerović, K. Tomović, Ž. Šmelcerović, Ž. Petronijević, G. Kocić, T. Tomašič, Ž. Jakopin, M. Anderluh, Xanthine oxidase inhibitors beyond allopurinol and febuxostat; an overview and selection of potential leads based on in silico calculated physico-chemical properties, predicted pharmacokinetics and toxicity, European Journal of Medicinal Chemistry, 135 (2017) 491-516.

[32] F. Borges, E. Fernandes, F. Roleira, Progress towards the discovery of xanthine oxidase inhibitors, Current Medicinal Chemistry, 9 (2002) 195-217.

[33] H.S. Virdi, S. Sharma, S. Mehndiratta, P.M. Bedi, K. Nepali, Design, synthesis and evaluation of 2,4diarylpyrano[3,2-c]chromen-5(4H)-one as a new class of non-purine xanthine oxidase inhibitors, Journal of Enzyme Inhibition and Medicinal Chemistry, (2014) 1-7.

[34] A. Duarte, S. Ferreira, S. Almeida, F.C. Domingues, Clinical isolates of Acinetobacter baumannii from a portuguese hospital: PFGE characterization, antibiotic susceptibility and biofilm-forming ability, Comparative Immunology, Microbiology and Infectious Diseases, 45 (2016) 29-33.

[35] A. Lu, Z. Wang, Z. Zhou, J. Chen, Q. Wang, Application of "hydrogen bonding interaction" in new drug development: design, synthesis, antiviral activity, and SARs of thiourea derivatives, Journal of Agricultural and Food Chemistry, 63 (2015) 1378-1384. 
[36] H. Schulte, Über die kondensation des $N, N^{\prime}$-diphenylthioharnstoffes mit malonylchlorid, Chemische Berichte, 87 (1954) 820-824.

[37] M.L. Deb, P.J. Bhuyan, Uncatalysed Knoevenagel condensation in aqueous medium at room temperature, Tetrahedron Letters, 46 (2005) 6453-6456.

[38] Q. Yan, R. Cao, W. Yi, Z. Chen, H. Wen, L. Ma, H. Song, Inhibitory effects of 5-benzylidene barbiturate derivatives on mushroom tyrosinase and their antibacterial activities, European Journal of Medicinal Chemistry, 44 (2009) 4235-4243.

[39] E. Soleimani, M.M. Khodaei, N. Batooie, M. Baghbanzadeh, Water-prompted synthesis of alkyl nitrile derivatives via Knoevenagel condensation and Michael addition reaction, Green Chemistry, 13 (2011) 566.

[40] B.S. Jursic, D.M. Neumann, Preparation of 5-formyl- and 5-acetylbarbituric acids, including the corresponding Schiff bases and phenylhydrazones, Tetrahedron Letters, 42 (2001) 8435-8439.

[41] M. Zhao, D. Zhu, D. Sun-Waterhouse, G. Su, L. Lin, X. Wang, Y. Dong, In vitro and in vivo studies on adlay-derived seed extracts: phenolic profiles, antioxidant activities, serum uric acid suppression, and xanthine oxidase inhibitory effects, Journal of Agricultural and Food Chemistry, 62 (2014) 7771-7778.

[42] D.N. Nicolaides, D.R. Gautam, K.E. Litinas, D.J. Hadjipavlou-Litina, K.C. Fylaktakidou, Synthesis and evaluation of the antioxidant and antiinflammatory activities of some benzo[1]khellactone derivatives and analogues, European Journal of Medicinal Chemistry, 39 (2004) 323-332.

[43] H.J. Tang, X.W. Zhang, L. Yang, W. Li, J.H. Li, J.X. Wang, J. Chen, Synthesis and evaluation of xanthine oxidase inhibitory and antioxidant activities of 2-arylbenzo[b]furan derivatives based on salvianolic acid C, European Journal of Medicinal Chemistry, 124 (2016) 637-648.

[44] J.P. Dzoyem, L.J. McGaw, J.N. Eloff, In vitro antibacterial, antioxidant and cytotoxic activity of acetone leaf extracts of nine under-investigated Fabaceae tree species leads to potentially useful extracts in animal health and productivity., BMC Complementary and Alternative Medicine, 14 (2014) 147-154.

[45] N. Dilek Özçelik, T. Tunç, R. Çatak Çelik, M. Erzengin, H. Özışık, Synthesis, spectroscopic, crystal structure, biological activities and theoretical studies of 2-[(2E)-2-(2-chloro-6fluorobenzylidene)hydrazinyl]pyridine, Journal of Molecular Structure, 1135 (2017) 98-105.

[46] F. Ghanbari Pirbasti, N.O. Mahmoodi, Facile synthesis and biological assays of novel 2,4-disubstituted hydrazinyl-thiazoles analogs, Molecular Diversity, 20 (2016) 497-506. 
[47] A. Grozav, I.-D. Porumb, I.L. Găină, L. Filip, D. Hanganu, Cytotoxicity and antioxidant potential of novel 2-(2-((1H-indol-5yl)methylene)-hydrazinyl)-thiazole derivatives, Molecules, 22 (2017).

[48] S. Mumtaz, R. Hussain, A. Rauf, M.Q. Fatmi, H. Bokhari, M. Oelgemöller, A.M. Qureshi, Synthesis, molecular docking studies, and in vitro screening of barbiturates/thiobarbiturates as antibacterial and cholinesterase inhibitors, Medicinal Chemestry Research, 23 (2014) 2715-2726.

[49] Y.-C. Jeong, M.G. Moloney, Antibacterial Barbituric Acid Analogues Inspired from Natural 3Acyltetramic Acids; Synthesis, Tautomerism and Structure and Physicochemical Property-Antibacterial Activity Relationships, Molecules, 20 (2015) 3582-3627.

[50] E. Giziroglu, C. Sarikurkcu, M. Aygün, G. Basbulbul, H.C. Soyleyici, E. Firinci, B. Kirkan, A. Alkis, T. Saylica, H. Biyik, Barbiturate bearing aroylhydrazine derivatives: Synthesis, NMR investigations, single crystal X-ray studies and biological activity, Journal of Molecular Structure, 1108 (2016) 325-333.

[51] Tacconelli, E. and Magrini, N. 2017. Global priority list of antibiotic-resistant bacteria to guide research, discovery, and development of new antibiotics. Retrieved from World Health Organization website. (http://www.who.int/entity/medicines/publications/WHO-PPL-Short_Summary 25Feb-

ET_NM_WHO.pdf?ua=1) (accessed September 6, 2017).

[52] M. Catarro, J. Serrano, E. Cavalheiro, S. Ramos, A.O. Santos, S. Silvestre, P. Almeida, Novel 4acetamide-2-alkylthio- $N$-acetanilides resembling nimesulide: Synthesis, cell viability evaluation and in silico studies, Bioorganic \& Medicinal Chemistry, 25 (2017) 4304-4313.

[53] T. Mosmann, Rapid colorimetric assay for cellular growth and survival: Application to proliferation and cytotoxicity assays, Journal of Immunological Methods, 65 (1983) 55-63.

[54] D.E. Pires, T.L. Blundell, D.B. Ascher, pkCSM: Predicting small-molecule pharmacokinetic and toxicity properties using graph-based signatures, Journal of Medicinal Chemistry, 58 (2015) 4066-4072.

[55] C.A. Lipinski, Drug-like properties and the causes of poor solubility and poor permeability, Journal of Pharmacological and Toxicological Methods, 44 (2000) 235-249.

[56] J.B. Baell, G.A. Holloway, New substructure filters for removal of pan assay interference compounds (PAINS) from screening libraries and for their exclusion in bioassays, Journal of Medicinal Chemistry, 53 (2010) 2719-2740.

[57] J. Baell, M.A. Walters, Chemical con artists foil drug discovery, Nature, 513 (2014) 481-483. 
[58] S.J. Capuzzi, E.N. Muratov, A. Tropsha, Phantom PAINS: Problems with the utility of alerts for panassay interference compounds, Journal of Chemical Information and Modeling, 57 (2017) 417-427.

[59] F. Wang, P. Zhao, C. Xi, Copper-catalyzed one-pot synthesis of 2-thioxo-2,3-dihydroquinazolin-4(1H)ones from ortho-bromobenzamides and isothiocyanates, Tetrahedron Letters, 52 (2011) 231-235.

[60] M. Kuanar, B.K. Mishra, Applicability of Williams-Norrington model for quantitative structure spectra relationship, Indian Journal of Chemistry, Section A: Inorganic, Bio-inorganic, Physical, Theoretical \& Analytical Chemistry, 34 (1995) 721-723.

[61] N. Seyyedi, F. Shirini, M.S. Nikoo Langarudi, DABCO-based ionic liquids: green and recyclable catalysts for the synthesis of barbituric and thiobarbituric acid derivatives in aqueous media, RSC Advances, 6 (2016) 44630-44640.

[62] M.K. Haldar, M.D. Scott, N. Sule, D.K. Srivastava, S. Mallik, Synthesis of barbiturate-based methionine aminopeptidase-1 inhibitors, Bioorganic \& Medicinal Chemistry Letters, 18 (2008) 2373-2376.

[63] J.A. Vida, C.M. Samour, M.H. O'Dea, T.S.T. Wang, W.R. Wilber, J.F. Reinhard, Analgesics. 1. Selected 5-substituted 5-propionoxybarbituric acids, Journal of Medicinal Chemistry, 17 (1974) 732-736.

[64] H.C. Scarborough, Pyrano[2,3-d]- and pyrido[2,3-d]pyrimidines, The Journal of Organic Chemistry, 29 (1964) 219-221.

[65] H. Biltz, H. Wittek, Über alkylierte und acylierte barbitursäuren, Berichte der Deutschen Chemischen Gesellschaft (A and B Series), 54 (1921) 1035-1058.

[66] P. Singh, J. Kaur, A. Bhardwaj, Synthesis of highly functionalized barbituric acids and study of their interactions with p-glycoprotein and $\mathrm{Mg}^{2+}$-potential candidates for multi drug resistance modulation, European Journal of Medicinal Chemistry, 45 (2010) 1256-1262.

[67] V.K. Ahluwalia, V.K. Garg, A. Dahiya, M.D. Alauddin, A convenient synthesis of 6-ethoxycarbonyl-4oxo-1,2,3,4-tetrahydro-7H-pyrano(2,3- $d$ )pyrimidin-7-ones, Indian Journal of Chemistry, Section B: Organic Chemistry Including Medicinal Chemistry, 34 (1995) 51-53.

[68] S. Gupta, L.M. Rodrigues, A.P. Esteves, A.M. Oliveira-Campos, M.S. Nascimento, N. Nazareth, H. Cidade, M.P. Neves, E. Fernandes, M. Pinto, N.M. Cerqueira, N. Bras, Synthesis of $N$-aryl-5-amino-4cyanopyrazole derivatives as potent xanthine oxidase inhibitors, European Journal of Medicinal Chemistry, 43 (2008) 771-780. 


\section{Figure Captions}

Figure 1. Enamine $\mathbf{A}$ and imine $\mathbf{B}$ tautomeric forms.

Figure 2. In vitro XO inhibitory activity of compounds $\mathbf{2 c}, \mathbf{2 d}, \mathbf{6 c - f}$ and allopurinol. Results are expressed as average values \pm standard error of the mean $(\mathrm{SEM})$. A $\mathrm{p}<0.05$ versus negative control in the statistical significance analysis (Student's $t$-test) was observed for all compounds except for $\mathbf{6 d}$.

Figure 3. In vitro DPPH radical scavenging activity for 5-hydrazinylethylidenepyrimidines 6a-g, 1-(pyrimidin-5ylidene)ureas 8d, $8 \mathbf{f}$ and Trolox (positive control). Results are expressed as average values \pm SEM. A $p<0.05$ versus negative control in the statistical significance analysis (Student's $t$-test) was observed for all compounds.

Figure 4. In vitro cytotoxic effect of compounds $\mathbf{6 c}, \mathbf{6 d}, 7 \mathbf{a}-\mathbf{j}$ and 5-fluorouracil (5-FU) in normal human dermal fibroblasts (NHDF) and in mammalian breast cancer cells (MCF-7). Results are expressed as average values \pm SEM. A $p<0.05$ versus negative control in the statistical significance analysis (Student's $t$-test) was observed for all compounds.

\section{Table Captions}

Table 1. In vitro $\mathrm{IC}_{50}$ values for XO inhibition and DPPH radical scavenging activity of compounds $\mathbf{2 c}, \mathbf{2 d}, \mathbf{6 c - e}$ and respective references allopurinol and Trolox.

\section{Scheme Captions}

Scheme 1. Chemical synthesis of BADs and TBADs 2-8.<smiles></smiles>

A<smiles>[X]C1=C([R])N([R])C(=O)C(C=NC)C1=O</smiles>

B

$\mathrm{X}=\mathrm{O}, \mathrm{S} ; \mathrm{R}=\mathrm{H}, \mathrm{CH}_{3}, \mathrm{Ph}$

Figure 1 


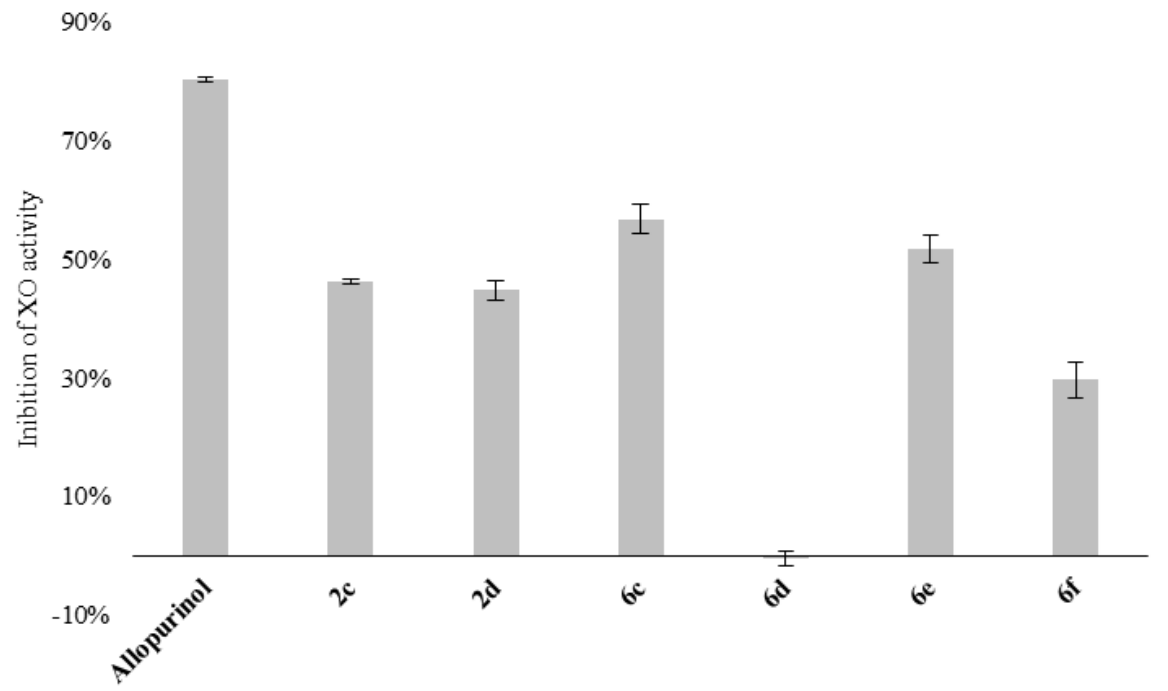

Figure 2

$90 \%$

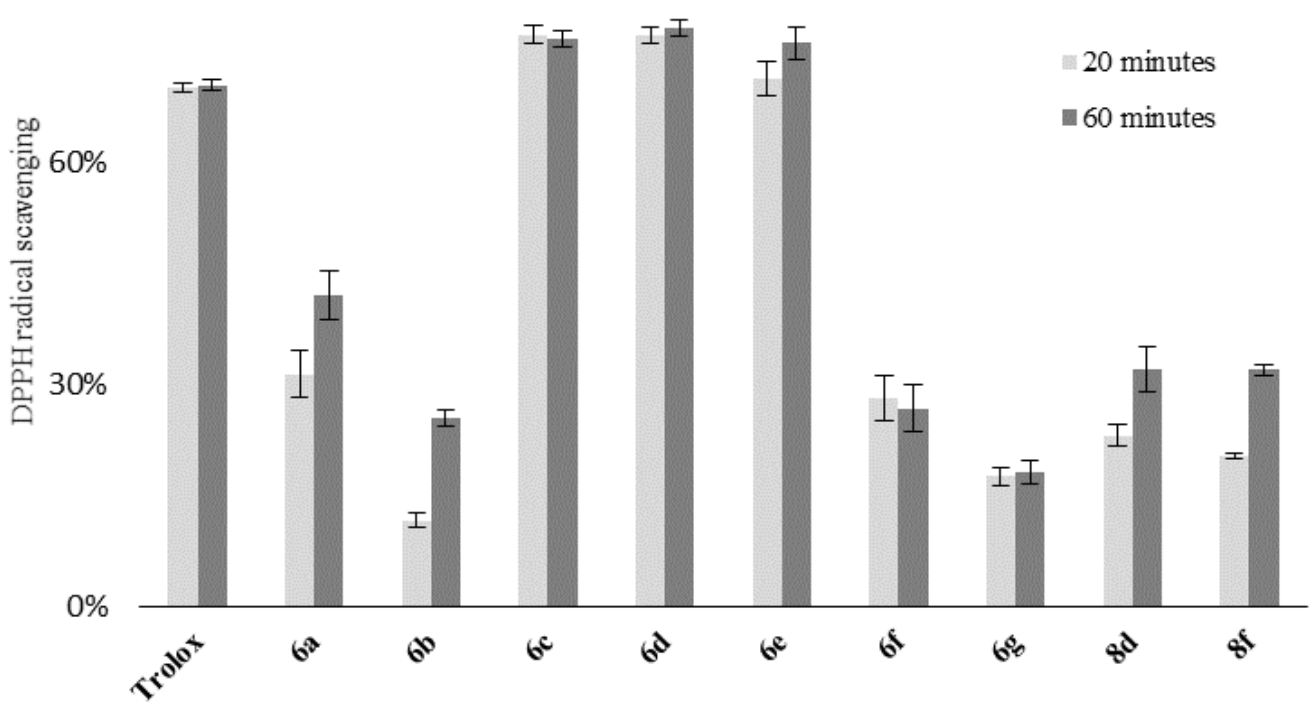

Figure 3 


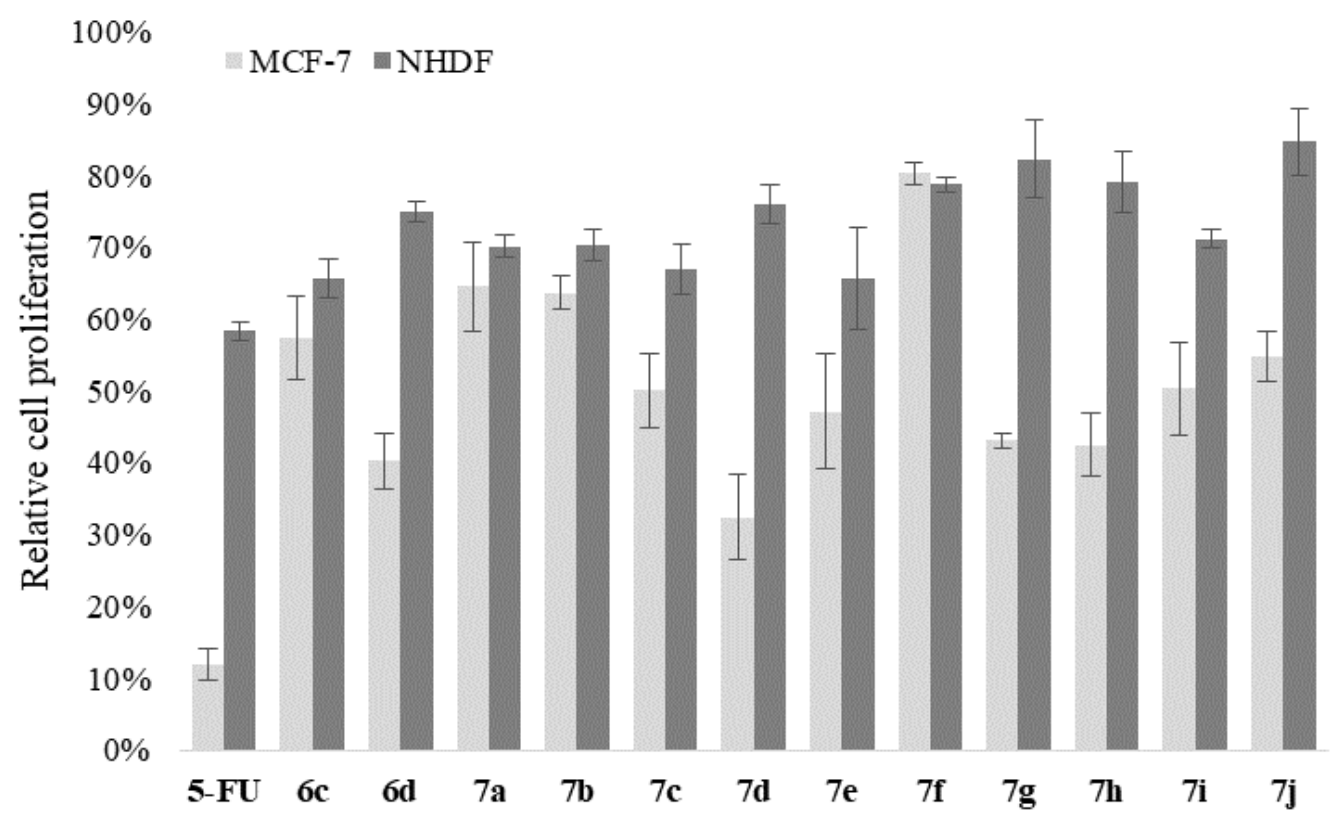

Figure 4

Table 1

\begin{tabular}{cccc}
\hline \multirow{2}{*}{ Compound } & \multirow{2}{*}{ XO $(\mu \mathrm{M})^{\mathrm{a}}$} & \multicolumn{2}{c}{$\mathrm{DPPH}(\mu \mathrm{M})^{\mathrm{a}}$} \\
\cline { 3 - 4 } & $20 \mathrm{~min}^{\mathrm{b}}$ & $60 \mathrm{~min}$ \\
\hline $\mathbf{2 c}$ & 26.1 & $\mathrm{nd}^{\mathrm{b}}$ & $\mathrm{nd}^{\mathrm{b}}$ \\
$\mathbf{6 d}$ & 31.5 & $\mathrm{nd}^{\mathrm{b}}$ & $\mathrm{nd}^{\mathrm{b}}$ \\
$\mathbf{6 c}$ & 24.3 & 22.6 & 18.8 \\
$\mathbf{6 e}$ & $\mathrm{nd}^{\mathrm{b}}$ & 23.9 & 20.4 \\
Allopurinol & 27.9 & 23.9 & 23.8 \\
Trolox & 3.2 & $\mathrm{nd}^{\mathrm{b}}$ & $\mathrm{nd}^{\mathrm{b}}$ \\
\hline
\end{tabular}

${ }^{\mathrm{a}} \mathrm{IC}_{50}$ values represent as mean of three determinations.

${ }^{\mathrm{b}}$ nd: not determined 


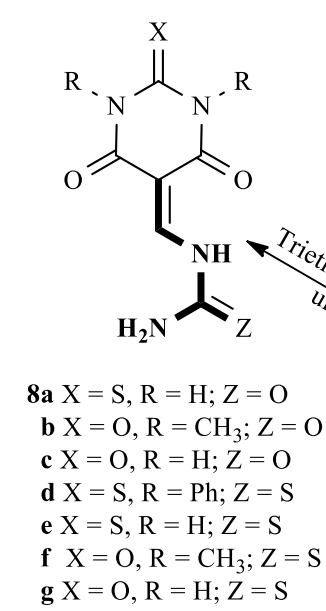<smiles>[Y]C1=C([Z1])N([Y8]([H])C)C(=O)C(=CNc2[Y10]cccc2)C1=O</smiles>

7a X $=\mathrm{S}, \mathrm{R}_{1}=\mathrm{H} ; \mathrm{R}_{2}=2-\mathrm{NH}_{2}$ b $\mathrm{X}=\mathrm{S}, \mathrm{R}_{1}=\mathrm{H} ; \mathrm{R}_{2}=2-\mathrm{Cl}, 5-\mathrm{NO}_{2}$ c $\mathrm{X}=\mathrm{O}, \mathrm{R}_{1}=\mathrm{CH}_{3} ; \mathrm{R}_{2}=2-\mathrm{Cl}, 5-\mathrm{NO}_{2}$ d $\mathrm{X}=\mathrm{S}, \mathrm{R}_{1}=\mathrm{H} ; \mathrm{R}_{2}=2-\mathrm{Cl}, 4-\mathrm{NO}_{2}$

e $\mathrm{X}=\mathrm{S}, \mathrm{R}_{1}=\mathrm{H} ; \mathrm{R}_{2}=2-\mathrm{Cl}$

f $\mathrm{X}=\mathrm{S}, \mathrm{R}_{1}=\mathrm{H} ; \mathrm{R}_{2}=2-\mathrm{NO}_{2}$ g X $=\mathrm{S}, \mathrm{R}_{1}=\mathrm{Ph} ; \mathrm{R}_{2}=2-\mathrm{COOH}$

h X $=\mathrm{S}, \mathrm{R}_{1}=\mathrm{H} ; \mathrm{R}_{2}=2-\mathrm{COOH}$ i X $=\mathrm{O}, \mathrm{R}_{1}=\mathrm{CH}_{3} ; \mathrm{R}_{2}=2-\mathrm{COOH}$ j X $=\mathrm{O}, \mathrm{R}_{1}=\mathrm{H} ; \mathrm{R}_{2}=2-\mathrm{COOH}$

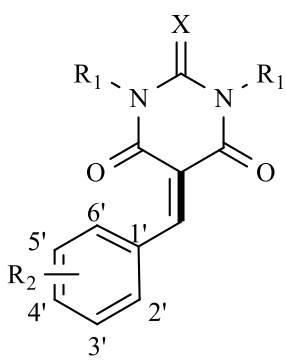

2a X $=\mathrm{S} ; \mathrm{R}_{1}=\mathrm{Ph} ; \mathrm{R}_{2}=2-\mathrm{NO}_{2}$

b X $=\mathrm{S} ; \mathrm{R}_{1}=\mathrm{H} ; \mathrm{R}_{2}=2-\mathrm{NO}_{2}$

c $\mathrm{X}=\mathrm{O} ; \mathrm{R}_{1}=\mathrm{CH}_{3} ; \mathrm{R}_{2}=2-\mathrm{NO}_{2}$

d X $=\mathrm{O} ; \mathrm{R}_{1}=\mathrm{H} ; \mathrm{R}_{2}=2-\mathrm{NO}_{2}$

e X $=\mathrm{O} ; \mathrm{R}_{1}=\mathrm{H} ; \mathrm{R}_{2}=4-\mathrm{OCH}_{3}$

$\mathrm{EtOH}, \mathrm{NaBH}_{4}, \mathrm{ct}$<smiles>COc1ccc(CC2C(=O)NC(=O)NC2=O)cc1</smiles>

1) $\mathrm{H}_{2} \mathrm{O}$, 4-Bromobenzaldehyde 2) $\mathrm{H}_{2} \mathrm{O}, \mathrm{NaCN}$ 4a $\mathrm{X}=\mathrm{S} ; \mathrm{R}=\mathrm{H}$ b $\mathrm{X}=\mathrm{O} ; \mathrm{R}=\mathrm{CH}_{3}$ c $\mathrm{X}=\mathrm{O} ; \mathrm{R}=\mathrm{CH}_{3}$ d $\mathrm{X}=\mathrm{O} ; \mathrm{R}=\mathrm{H}$

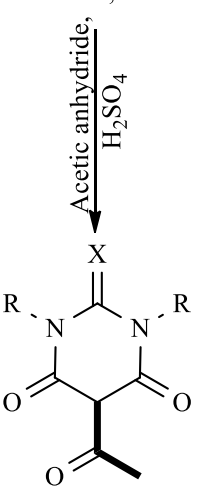

5a $\mathrm{X}=\mathrm{S} ; \mathrm{R}=\mathrm{Ph}$ b $\mathrm{X}=\mathrm{O} ; \mathrm{R}=\mathrm{CH}_{3}$ c $\mathrm{X}=\mathrm{O} ; \mathrm{R}=\mathrm{H}$<smiles>[R4]NNC(C)=c1c(=O)n([R3])c(=[X])n([R3])c1=O</smiles>
6a $X=S ; R_{1}=P h ; R_{2}=H$ b X $=\mathrm{O} ; \mathrm{R}_{1}=\mathrm{H} ; \mathrm{R}_{2}=\mathrm{H}$ c $\mathrm{X}=\mathrm{O} ; \mathrm{R}_{1}=\mathrm{CH}_{3} ; \mathrm{R}_{2}=\mathrm{C}_{6} \mathrm{H}_{5}$ d X $=\mathrm{O} ; \mathrm{R}_{1}=\mathrm{H} ; \mathrm{R}_{2}=\mathrm{C}_{6} \mathrm{H}_{5}$ e X $=\mathrm{O} ; \mathrm{R}_{1}=\mathrm{CH}_{3} ; \mathrm{R}_{2}=4-\mathrm{NO}_{2} \mathrm{C}_{6} \mathrm{H}_{4}$ f X $=\mathrm{O} ; \mathrm{R}_{1}=\mathrm{CH}_{3} ; \mathrm{R}_{2}=2,4-\mathrm{NO}_{2} \mathrm{C}_{6} \mathrm{H}_{3}$ g X $=\mathrm{O} ; \mathrm{R}_{1}=\mathrm{H} ; \mathrm{R}_{2}=2,4-\mathrm{NO}_{2} \mathrm{C}_{6} \mathrm{H}_{3}$

Scheme 1 